\title{
Association of novel monomethine cyanine dyes with bacteriophage MS2: a fluorescence study
}

\author{
Kateryna Vus ${ }^{1}$, Uliana Tarabara ${ }^{1}$, Zita Balklava ${ }^{2}$, Dmitry Nerukh ${ }^{3}$, Michael Stich $^{3}$, Anna \\ Laguta $^{4}$, Natalya Vodolazkaya ${ }^{4}$, Nikolay O. Mchedlov-Petrossyan ${ }^{4}$, Vladimir Farafonov ${ }^{4}, \mathrm{Nika}$ \\ Kriklya $^{4}$, Galyna Gorbenko ${ }^{1}$, Valeriya Trusova ${ }^{1}$, Olga Zhytniakivska ${ }^{1}$, Atanas Kurutos ${ }^{5}$, Nikolai \\ Gadjev $^{6}$, Todor Deligeorgiev ${ }^{6}$
}

${ }^{1}$ Department of Nuclear and Medical Physics, V.N. Karazin Kharkiv National University, 4 Svobody Sq., Kharkiv 61022, Ukraine;

${ }^{2}$ Department of Life and Health Sciences, Aston University, Birmingham, B4 7ET, United Kingdom;

${ }^{3}$ Department of Mathematics, Aston University, Birmingham, B4 7ET, United Kingdom;

${ }^{4}$ Department of Physical Chemistry, V.N. Karazin Kharkiv National University, 4 Svobody Sq., Kharkiv 61022, Ukraine;

${ }^{5}$ Institute of Organic Chemistry with Centre of Phytochemistry, Bulgarian Academy of Sciences, Acad. G. Bonchev str., bl. 9, 1113 Sofia, Bulgaria;

${ }^{6}$ Department of Pharmaceutical and Applied Organic Chemistry, Faculty of Chemistry, Sofia University St. Kliment Ohridski, 1 blv. J. Bourchier, Sofia, 1164, Bulgaria

\begin{abstract}
Novel monomethine cyanine dyes Cl-YO, F-YO, Cl-YO-Et, Cl-YO-Bu, and YO-Pent were evaluated as agents to detect and characterise a small virus, the MS2 bacteriophage, using the dye and virus intrinsic fluorescence, kinetic and thermal properties, chemical denaturation, and molecular docking and quantum chemistry modelling. The examined compounds demonstrated enhanced fluorescence responses and high affinities $\left(\sim 1 \mu \mathrm{M}^{-1}\right)$ for the intact bacteriophage at physiological ionic strength. The linear Scatchard plots revealed the existence of one binding mode for most dyes. Strong evidence that the cyanines bind to the bacteriophage external surface were obtained, although the possibility of the dye penetration through the virus shell and subsequent complexation with the viral RNA was also tested. The main arguments in favour of the former were that i) the fluorescence of the MS2-bound fluorophores decreased under the influence of protein denaturants, urea and guanidine hydrochloride; ii) the fluorescence responses of the dyes to MS2 and bovine serum albumin were similar; and (iii) one order of magnitude higher sensitivity of the dyes to the yeast RNA was found. Simple docking studies suggested that one cyanine molecule is trapped in a cleft formed by three proteins composing the
\end{abstract}


virus shell. Significant role of electrostatic forces in the stabilisation of the dye-MS2 complexes at low ionic strength $(10 \mathrm{mM})$ was demonstrated, while the influence of steric, hydrophobic, and van-der-Waals interactions was expected to increase at physiological ionic strength. The spectral properties of the novel cyanine dyes compared to other fluorophores demonstrated higher sensitivity of the cyanines to MS2, rendering them promising agents for the investigation of the changes in the virus structure under the influence of heat (Cl-YO-Et, Cl-YO-Bu), denaturants (Cl-YO, F-YO), and ionic strength (all the compounds).

Key words: MS2 bacteriophage; cyanine dyes; fluorescence; MS2 capsid; Scatchard plots; dye-capsid interactions

\section{Corresponding author:}

Dr. Kateryna Vus

Svodody St. 6, Kharkiv 61022, Ukraine

Tel: (+380 57) 3438244

E-mail: kateryna_vus@yahoo.com 


\section{Introduction}

Viruses have long been a focus of great research interest in a variety of aspects due to their medical relevance, from the viral infection cycle to the virus-based drug nanocarriers and gene therapy [1,2]. The MS2 bacteriophage, a small non-enveloped RNA phage that infects Escherichia coli [3], has been extensively used as a model virus for immunological [4], evolutionary [5] and water disinfection [5,6-9] studies, since its size ( 27 nm), RNA and capsid structure are similar to those of enteric pathogenic viruses [10]. Specifically, its single stranded RNA (3569 nucleotides, $1600 \mathrm{kDa}[11,12]$ ) is electrostatically attached to the phage's $\mathrm{T}=3$ icosahedral capsid composed of 178 copies of the coat protein and an asymmetric maturation protein [13]. The MS2 RNA packaging and its capsid formation are closely connected: i) the RNA hairpins promote the arrangement of the coat protein dimers into pentameric nuclei, thus, accelerating the capsid formation [10]; ii) the genome forms two concentric shells, connected along the 5-fold symmetry axes of the capsid [14]. MS2 is a soft bioparticle, because it is permeable to water, ions, and small molecules [15] due to the presence of 32 pores, each $1.8 \mathrm{~nm}$ in diameter, covering more than $10 \%$ of the capsid surface. Therefore, the phage has three structurally different layers, i.e. the capsid outer shell (thickness $\sim 2 \mathrm{~nm}$ ), the capsid-bound RNA layer (thickness $\sim 3 \mathrm{~nm}$ ), and the fully hydrated bulk RNA (filling a nearly spherical volume with $\sim 8 \mathrm{~nm}$ radius) [14,16]. The capsid outer surface is negatively charged at neutral $\mathrm{pH}$ [17], and it is stable within the $\mathrm{pH}$ range $3-9$ [18]. The all-atom model of the MS2 capsid at physiological conditions has built recently [17] and the effect of ion distribution on the capsid's surface stability was analysed using Molecular Dynamics simulations [19]. The above structural and physicochemical properties of MS2 enable the encapsulation of the RNAs, DNAs [20], radioactive isotopes, anticancer agents [21] into an empty MS2 capsid and the modification of its exterior surface [22], resulting in the design of MS2-based drug delivery systems [20], highly sensitive diagnostic tools [21], and building blocks for material construction [22].

One of the most powerful experimental approaches currently employed to uncover the infectivity mechanisms of viruses and to extend the area of their biomedical applications involves the use of fluorescence techniques. Fluorescence studies have been performed on many viruses, including the measurements of: i) the intrinsic fluorescence of viral proteins [23,24]; ii) the spectral responses of the viral RNA covalent labels, e.g. SYBR gold [24], YOYO-1 [25] (for bacteria detection); and iii) the fluorescence of the capsid labels, viz. Rhodamine B (for the estimation of disinfectant doses for viruses) [26], carbocyanines Cy5 (for the development of capsid-based DNA markers) [27] and Cy3 (for cell imaging and flow cytometry) [28], fluorescein (for investigation of viral transport in porous media) [29], Alexa dyes (for the in vivo visualization of the tumor angiogenesis in mice [30] and for devising the photocatalytic materials 
[30]), etc. Despite the simplicity and efficiency non-covalent labeling of whole viruses and viruslike particles (VLPs) has rarely been used so far because of the difficulties in the quantitative characterisation of the dye-virus complexes and determining the precise location of the bound fluorophores. For example, Nano Orange has been used as a fluorescent marker for MS2 and the MS2-antibody immunocomplex [4], the cyanine dyes YO, YO-PRO, YO-PRO17, BOXTO-PRO were found to be suitable for monitoring the bacteriophage T5 capsid permeability for small molecules [31]. In this respect, the cyanines represent an attractive class of fluorescent markers whose main advantages lie in the high extinction coefficients, long-wavelength absorption, and emission covering the optical window for biological samples [32,33]. The cyanine dyes have been successfully employed as fluorescent markers of nucleic acids and proteins [34], smallmolecule agents for tumor-specific drug delivery [35], tumor photodynamic therapy [36], inhibitors of amyloid fibril formation [37] to name a few.

The present study was undertaken to assess the ability of the novel monomethine cyanine dyes to detect and characterise the MS2 bacteriophage using the fluorescence spectroscopy technique. Specifically, our objectives were i) to qualitatively and quantitatively analyse the dyebacteriophage interactions; and ii) to determine what structural component of the MS2 phage (capsid or RNA) preferentially accommodates the examined fluorophores by investigating the effects of heating, ionic strength, ribonuclease (RNase), urea and guanidine hydrochloride $(\mathrm{GdnHCl})$ on the dye spectral responses.

\section{Materials and methods}

\subsection{Chemicals and microorganisms}

The grades of the reagents used were as follows. Bovine serum albumin (BSA, $\geq 96 \%$, agarose gel electrophoresis), dimethyl sulfoxide (99\%, ACS reagent), guanidine hydrochloride $\geq 98 \%$ ), ribonuclease A from bovine pancreas ( $\geq 60 \%$ RNase A basis, SDS-PAGE), 1anilinonaphthalene-8-sulfonic acid (1,8-ANS, high purity), Thioflavin $\mathrm{T}(\geq 65 \%), \mathrm{NaCl}$ (chemically pure, 99.9\%), and RNA from Saccharomyces cerevisiae (95\%, Pi (phosphate): 0.3\%), phosphotungstic acid hydrate (high-purity grade) for electron microscopy were obtained from Sigma (St. Louis, MO). Acridine Orange and Methylene Blue (high-purity grade), urea, $\mathrm{Na}_{2} \mathrm{CO}_{3}, \mathrm{CuSO}_{4} \cdot 5 \mathrm{H}_{2} \mathrm{O}$, sodium citrate, $\mathrm{NaOH}$ and Folin-Ciocalteau phenol reagent (all pure for analysis) were from Reakhim (Russia). TRIS (assay min. $99.9 \%$, titration) was purchased from Serva. The monomethine cyanine dyes (analytical grade) (Scheme 1), the trimethine cyanine AK3-1 and phosphonium dye TDV (analytical grade) were synthesized and purified in the University of Sofia, Bulgaria, as described previously [38]. 
The coliphage MS2 (ATCC 15597-B1) and its host E. coli strain C-3000 (ATCC 15597) were obtained from American Type Culture Collection (ATCC), followed by their propagation, expression and purification as described below.

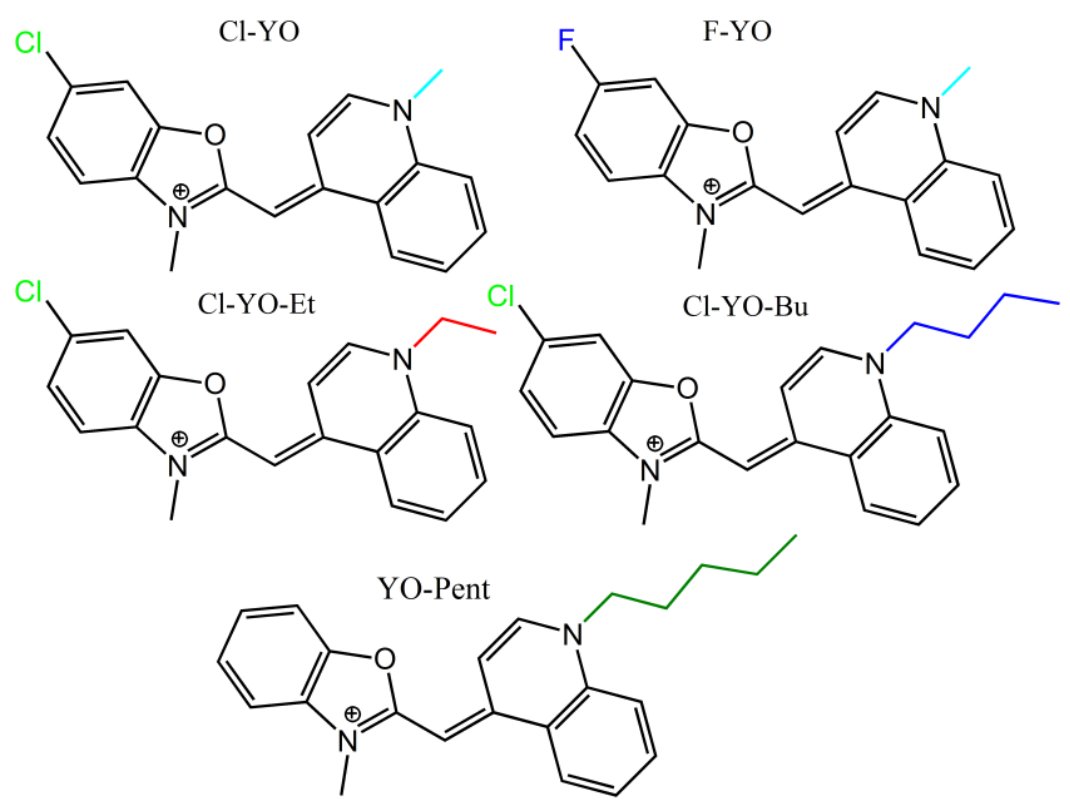

\section{Scheme 1.}

Structures of the monomethine cyanine dyes under study.

$\mathrm{CaCl}_{2}$ (USP grade), $\mathrm{MgCl}_{2}$ (analytical grade), TRIS (ultrapure) used for the MS2 phage production and purification, were from Melford Laboratories, UK. $\mathrm{NaCl}$ (analytical grade) was from Duchefa (Netherlands). All other chemicals were used without further purification.

\subsection{MS2 propagation, expression and purification}

Two series of MS2, referred to here as $\mathrm{ms} 2 / \mathrm{s} 1$ and $\mathrm{ms} 2 / \mathrm{s} 2$, were prepared and used in this study. Bacteria E. coli were cultured in Lennox L Broth medium (Melford Laboratories) at $37^{\circ} \mathrm{C}$ and infected with MS2 phage at middle log-phase. After complete lysis of the bacteria within a few hours, the lysate was centrifuged at $10,000 \mathrm{~g}$ for $15 \mathrm{~min}$ to remove cell debris, and then centrifuged again at $100,000 \mathrm{~g}$ for $4 \mathrm{~h}$ to pellet the phage particles [39]. The pellet was resuspended in buffer containing $50 \mathrm{mM}$ TRIS (pH 7.5), $150 \mathrm{mM} \mathrm{NaCl}, 5 \mathrm{mM} \mathrm{CaCl}_{2}$ and $5 \mathrm{mM}$ $\mathrm{MgCl}_{2}$, revealing the first series of the particles (ms2/s1) [31]. The same protocol was employed for the preparation of the second series of MS2 (ms2/s2), although ultracentrifugation at 100,000 $\mathrm{g}$ was not used in this case in order to reduce the extent of the phage aggregation [24]. Instead, MS2 was concentrated using Amicon_Ultra-15 centrifugal filter units containing Ultracel 100 $\mathrm{kDa}$ membrane. The ms2/s1 was viewed by TEM (Figure S1A) [31]. The infective MS2 phage 
concentration was determined by a plaque forming unit (PFU) assay using the overlay method [40], yielding the values $10^{6} \mathrm{PFU} / \mathrm{mL}(\mathrm{ms} 2 / \mathrm{s} 1)$ and $10^{14} \mathrm{PFU} / \mathrm{mL}(\mathrm{ms} 2 / \mathrm{s} 2)$.

The MS2 amount was also quantified using the Lowry method (Figure S1B), and expressed in $\mathrm{mg}$ protein per $\mathrm{ml}$ [41]. The total protein concentrations revealed by this method were $3.2 \pm 0.6$ $\mathrm{mg} / \mathrm{ml}(\mathrm{ms} 2 / \mathrm{s} 1)$ and $25 \pm 5 \mathrm{mg} / \mathrm{ml}(\mathrm{ms} 2 / \mathrm{s} 2)$, respectively.

\subsection{Preparation of working solutions}

Cyanine dye stock solutions $(50 \mu \mathrm{M})$ were prepared in dimethyl sulfoxide. To determine the dye concentration, the absorption spectra of the diluted stock solutions (Figure S2) were measured with the Hitachi U-2000 spectrophotometer (Hitachi, Japan). The extinction coefficients at the absorption maxima $482-485 \mathrm{~nm}$ for the monomethine cyanine dyes, referred to here as Cl-YO, F-YO, Cl-YO-Et, Cl-YO-Bu, YO-Pent, were $72600 \mathrm{M}^{-1} \mathrm{~cm}^{-1}, 60300 \mathrm{M}^{-1} \mathrm{~cm}^{-1}$, $64000 \mathrm{M}^{-1} \mathrm{~cm}^{-1}, 90500 \mathrm{M}^{-1} \mathrm{~cm}^{-1}, 90400 \mathrm{M}^{-1} \mathrm{~cm}^{-1}$, respectively. The MS2 working solutions, yeast RNA $(0.5 \mathrm{mg} / \mathrm{ml})$, bovine serum albumin $(7 \mathrm{mg} / \mathrm{ml})$ and RNase $(10 \mathrm{mg} / \mathrm{ml})$ stock solutions were prepared in TRIS buffer ( $\mathrm{pH} 7.5,50 \mathrm{mM}$ TRIS, $150 \mathrm{mM} \mathrm{NaCl}, 5 \mathrm{mM} \mathrm{CaCl}, 5 \mathrm{mM} \mathrm{MgCl} 2$ ), referred to here as TRIS-MS2 buffer. The $5 \mathrm{M} \mathrm{NaCl}$ was prepared by the salt dissolution in sodium phosphate buffer (5 mM, pH 7.4). The urea (8.3 M) and $\mathrm{GdnHCl}(6 \mathrm{M})$ stock solutions were prepared in distilled water. To study the effects of ionic strength on the dye binding to $\mathrm{ms} 2 / \mathrm{s} 2$ some experiments were also performed in TRIS buffer (10 mM TRIS, pH 7.5).

\subsection{Steady-state fluorescence measurements}

The emission spectra of the cyanine dyes were recorded in buffer and in the presence of MS2, RNA, BSA, RNase, urea, and GdnHCl with LS-55 spectrofluorimeter (Perkin-Elmer Ltd., UK) at $20{ }^{\circ} \mathrm{C}$ using $10 \mathrm{~mm}$ path-length quartz cuvettes. For all the examined cyanines the excitation wavelength was $460 \mathrm{~nm}$, with excitation and emission slit widths being set at $10 \mathrm{~nm}$. While measuring the intrinsic protein fluorescence of the intact, heat-denatured, urea-denatured and GdnHCl-denatured ms2/s2, the excitation wavelength was $280 \mathrm{~nm}$. The fluorescence kinetic measurements of the dye binding to the heat-, RNase-, and urea-treated ms $2 / \mathrm{s} 2$ were performed at emission wavelength $504 \mathrm{~nm}$, with the time step $0.001 \mathrm{~min}$, the excitation wavelength $460 \mathrm{~nm}$, and the excitation and emission slit widths $10 \mathrm{~nm}$.

\subsection{Binding studies}

A simple one-site Langmuir adsorption model was employed to quantitatively analyse the binding of the cyanine dyes to ms2/s1. To quantify the amount of MS2-associated ThT, it was 
assumed that the fluorescence intensity increase accompanying the formation of the dye-virus complex $\left(\Delta F_{504}\right)$ is proportional to the concentration of the bound dye $(B)[42,43]$ :

$$
\Delta F_{504}=F-F_{0}=F_{m o l} B
$$

where $F_{0}$ is the dye fluorescence intensity in the buffer solution, $F_{m o l}$ is a coefficient proportional to the difference of the dye quantum yields in the free and virus-associated states. In terms of the Langmuir adsorption model the concentration of the bound dye can be represented as a function of the total concentrations of the dye $(Z)$ and protein $(P)$, association constant $\left(K_{a}\right)$ and binding stoichiometry $(n, \mathrm{~mol}$ of dye $/ \mathrm{mg}$ of protein per $\mathrm{ml}$ ) using the following expression:

$$
K_{a}=\frac{B}{(Z-B)(n P-B)}=\frac{B}{F(n P-B)}
$$

where $F$ is the concentration of the free dye. In the case when $n P>>B$, from eqs. (1) and (2) one obtains:

$$
\frac{1}{\Delta F_{504}}=\frac{1}{F_{m o l} n P K_{a} Z}+\frac{1}{F_{m o l} Z}
$$

The y-intercept of the $1 / \Delta F_{504}$ vs. $1 / P$ equals $1 / F_{m o l} Z$, thus yielding the value of $F_{\text {mol }}$ required for calculating $B$ from eq. (1). Next, the association constant and stoichiometry of the dye-virus binding were estimated from the fluorimetric titration of $\mathrm{ms} 2 / \mathrm{s} 1$ by the dye. The concentration of the bound dye, $B$, at each titration point was calculated as $\Delta F_{504} / F_{\text {mol }}$, and the concentration of the free dye equals to $F=Z-B$. The Scatchard plots $B / F=f(B)$ were used to calculate $K_{a}=-b_{1}$, and $n=-b_{0} /\left(b_{1} \cdot P\right)$, where $b_{1}$ and $b_{0}$ are the slope and the intercept of the linear fit of the plot $B / F(B)$ [44]. The same approach was employed to quantify the dye association with RNA and estimating the $F_{m o l}$ value for the Cl-YO - BSA complex.

\subsection{Effects of heat, ribonuclease, $\mathrm{NaCl}$ and denaturants on the dye-virus binding}

To examine the effect of heating on the dye binding to $\mathrm{ms} 2 / \mathrm{s} 2,2 \mathrm{ml}$ of the phage $(0.06 \mathrm{mg}$ protein per $\mathrm{ml}$ ) was incubated in water bath at $72{ }^{\circ} \mathrm{C}$ for $20 \mathrm{~min}$ [45], cooled to the room temperature, followed by the addition of $20 \mu \mathrm{l}$ of the dye (to final concentration $0.5 \mu \mathrm{M}$ ) and subsequent kinetics measurements for $5 \mathrm{~min}$ at room temperature. The control sample was prepared with the intact ms2/s2 (0.06 mg protein per $\mathrm{ml})$ and $0.5 \mu \mathrm{M}$ of the dye. The fluorescence spectra of the phage-bound dyes were also measured after the equilibration was completed. 
The RNase effects were studied by adding $50 \mu 1$ RNase (to reach its final concentration 0.24 $\mathrm{mg} / \mathrm{ml})$ to the heat-denatured and intact $\mathrm{ms} 2 / \mathrm{s} 2(0.06 \mathrm{mg}$ protein per $\mathrm{ml})$, followed by the kinetics measurements for $5 \mathrm{~min}$ at room temperature.

An additional series of experiments was conducted to evaluate the urea and $\mathrm{GdnHCl}$ denaturing effects on the MS2 phage. The ms2/s2 (0.06 mg protein per ml) suspended in the mixture of $1 \mathrm{ml}$ TRIS-MS2 buffer and $1 \mathrm{ml}$ urea $(8.33 \mathrm{M})$ or $\mathrm{GdnHCl}(6 \mathrm{M})$ was incubated for 16 hours at room temperature [24], followed by the addition of the cyanine dye Cl-YO (to a final concentration of $0.5 \mu \mathrm{M}$ ) and measurements of its fluorescence spectra. The control samples contained the dye, buffer, and urea or $\mathrm{GdnHCl}$. Alternatively, the kinetics measurements were conducted after urea (to a final concentration of $0.44 \mathrm{M}$ ) addition to the sample, containing the dye $(2 \mu \mathrm{M})$ and intact MS2 (0.001 mg protein per $\mathrm{ml})$.

The effects of $\mathrm{NaCl}$ on the dye binding to the intact and heat-denatured ms $2 / \mathrm{s} 2(0.06 \mathrm{mg}$ protein per $\mathrm{ml}$ ) were studied by the fluorescence spectra measurements of the $\mathrm{ms} 2 / \mathrm{s} 2$-bound cyanines $(0.5 \mu \mathrm{M})$ in TRIS-MS2 and TRIS (10 mM, pH 7.5) buffers, followed by the comparison of the fluorescence intensities at $504 \mathrm{~nm}$. Furthermore, the dye spectral response was also registered after the addition of $\mathrm{NaCl}$ (to a final concentration of $1 \mathrm{M}$ ) to the above solutions of the MS2-bound cyanines. The relative change in the fluorescence intensity of the cyanines at $504 \mathrm{~nm}$ was calculated as follows:

$$
\text { Change, } \%=\frac{I-I_{0}}{I_{0}} \cdot 100 \%,
$$

where $I_{0}$ and $I$ are initial fluorescence intensity of the MS2-bound dye, and the intensity measured after the virus modification by heat or denaturants, respectively.

\subsection{Quantum chemistry calculations}

The dye geometry optimisation and estimation of their quantum chemistry parameters, such as i) the energy of the highest occupied ( EHOMO ) and lowest unoccupied ( ELUMO ) molecular orbitals; ii) the solvent accessible area ( $C A)$; iii) the COSMO volume (molecular volume) $(C V)$; iv) the molecular length $(L)$, height $(H)$ and width $(W)$, were performed with the semiempirical PM6 method (MOPAC 2016 Version18.012L - free academic license $[46,47]$ ). The Molinspiration software (http://www.molinspiration.com/cgi-bin/properties) was used for evaluating the lipophilicity of the examined compounds $(\log P$ ) (http://www.vcclab.org/lab/alogps/) [48]. All the calculated parameters are presented in Table S1. 


\subsection{Molecular docking}

To identify possible MS2 binding sites for the cyanine dyes and to elucidate the nature of the interactions involved in the dye-protein complexation in the virus capsid, the molecular docking studies were carried out with the all-atom model of MS2 capsid built using the combination of high resolution cryo-EM measurements and molecular dynamics simulations (under physiological conditions) [17]. The two subunits of MS2 capsid: i) a trimer (composed of two $\mathrm{A} / \mathrm{B}$ dimers and one $\mathrm{C} / \mathrm{C}$ dimer of the virus), ii) a pentamer (composed of five $\mathrm{A} / \mathrm{B}$ dimers) were chosen as representatives to simplify the calculations $[17,20]$. Alternatively, the structure of the ssRNA stem-loop (with the nucleotide sequence UGAGGAUCACCCA), taken from the MS2 coat protein/RNA complex (PDB ID: 1ZDH) [49], was used to identify potential MS2 RNA binding sites for the novel dyes. The structures of the dye monomers optimised using the semiempirical PM6 method [46,47] were used for the docking studies, because the monomer dye species are predominant in buffer solution at micromolar concentrations employed here (Figure S1B) $[50,51]$. The top 10 energetically favourable dye-protein structures were obtained using the PatchDock algorithm that is suitable for protein-ligand and protein-protein complexes, and then refined by the FireDock, as described previously [52]. The docked complexes were visually examined by the Visual Molecular Dynamics (VMD) software (version 1.9.3).

\section{Results and discussion}

\subsection{Qualitative analysis of the dye-MS2 binding}

At the first stage of our study the dye-virus association time profiles were measured (as described in Section 2.7) revealing very fast and significant fluorescence response of the examined cyanines to the presence of $\mathrm{ms} 2 / \mathrm{s} 2$, similar to that of YO-PRO to the bacteriophage T5 [31]. Representative curves are shown in Figure 1 that indicate the comparable rates of the dye association with the intact and heat-denatured (as described in Section 2.9) phage. To rationalize these findings, two basic hypotheses were considered: i) the dye predominant binding to the MS2 capsid (hypothesis 1) and ii) the dye preferential association with the viral RNA (hypothesis 2).

Hypothesis 1. The immediate formation of the dye-MS2 complex (Figure 1A) is most likely to occur on the phage exterior, because cyanine penetration through the capsid pores should result in a slower rate of binding. Indeed, despite the genome-free MS2 capsid surface is permeable to small molecules, for example fluorescein-aniline conjugates [15], uranyl acetate [22], hybrid oligonucleotides [53], etc., high RNA density near the pentamer pore is likely to impose steric restrictions to the dye binding inside the phage [14,22]. Presumably, only small species like ions or singlet oxygen are capable of reaching the MS2 capsid interior [17,22,54]. In turn, a large number of small ligands were reported to associate with the MS2 capsid through 


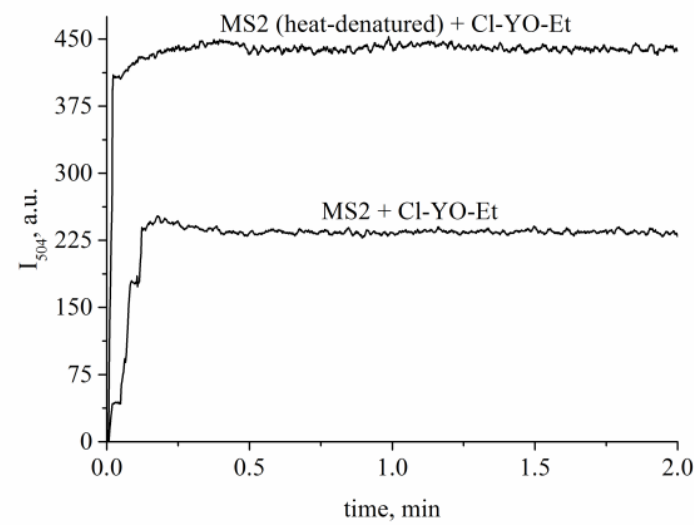

A

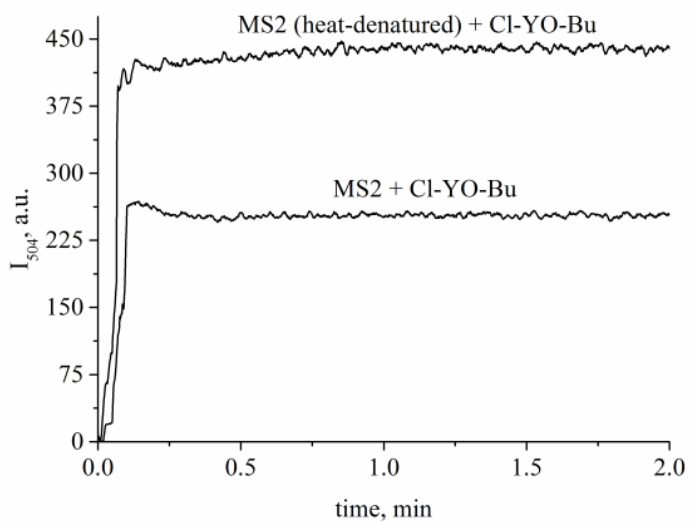

B

\section{Figure 1.}

Kinetics of association of Cl-YO-Et (A) and Cl-YO-Bu (B) with intact and heat-denatured at 72 ${ }^{\circ} \mathrm{C} \mathrm{ms} 2 / \mathrm{s} 2(0.06 \mathrm{mg}$ protein per $\mathrm{ml})$, monitored by the increase in fluorescence intensity at 504 nm.

covalent interactions

(fluorescein-5-isothiocyanate,

fluorescein, $5-(4,6-$ dichlorotriazinyl)aminofluorescein [29]) and non-covalent/hydrophobic (Nano Orange [4,55], rhodamine B [29], Sypro Orange [45]).

Hypothesis 1. The immediate formation of the dye-MS2 complex (Figure 1A) is most likely to occur on the phage exterior, because cyanine penetration through the capsid pores should result in a slower rate of binding. Indeed, despite the genome-free MS2 capsid surface is permeable to small molecules, for example fluorescein aniline conjugates [15], uranyl acetate [22], hybrid oligonucleotides [53], ete., high RNA density near the pentamer pore is likely to impose steric restrictions to the dye binding inside the phage $[14,22]$. Presumably, only small species like ions or singlet oxygen are capable of reaching the MS2 capsid interior $[17,22,54]$. In turn, a large number of small ligands were reported to associate with the MS2 capsid through covalent interactions (fluorescein-5-isothiocyanate, fluorescein, 5-(4,6dichlorotriazinyl)aminofluorescein [29]) and non-covalent/hydrophobic (Nano Orange [4,55], rhodamine B [29], Sypro Orange [45]). Thus, low probability of the dye collision with the MS2 pore edge (total pore area is only $14 \%$ of the capsid surface) along with the theoretically predicted possibility of the pore size decrease upon increasing the ionic strength (up to $1 \mathrm{~nm}$ at the ionic strength $100 \mathrm{mM}$ ) [16], strongly suggest that the cyanines associate with the capsid of the intact virus. Interestingly, the fast rates of the dye binding to the intact and heat-denatured 
MS2 may reflect similar kinetic behaviours of the cyanine complexation with the capsid protein and RNA/RNA-denatured protein assemblies [45].

Hypothesis 2. On the other hand, it cannot be excluded that at least some part of the dye molecules can penetrate the capsid shell and associate with the viral RNA, because the pore diameter $(\sim 1.8 \mathrm{~nm})$ is greater than the longest dimension of the investigated cyanines varying between 1.26 and $1.57 \mathrm{~nm}$ (Table S1). One should also bear in mind that the cationic YO probes have been developed as specific DNA and RNA fluorescent markers [50,51]. Furthermore, a fast rate of the cyanine YO-PRO binding to bacteriophage T5 was attributed to the dye association with the phage DNA packed inside the capsid [31]. Finally, a molecular probe Sypro Orange (that is longer than the compounds under study) was assumed to penetrate inside the MS2 particles after the phage heating to $60{ }^{\circ} \mathrm{C}$ [45].

\subsection{Quantitative analysis of the dye-MS2 binding}

Taking into account the above considerations, our further efforts were focused on evaluating the dye affinities to MS2, and identifying the possible phage sites for the cyanine accommodation. Since the equilibrium between the free and MS2-bound dye species was established immediately (Figure 1), the fluorescence titrations of the fluorophores with ms $2 / \mathrm{s} 1$, and vice versa, were performed. As seen in Figures 2, S3-S5, all examined cyanines showed substantial fluorescence increase in the presence of MS2.

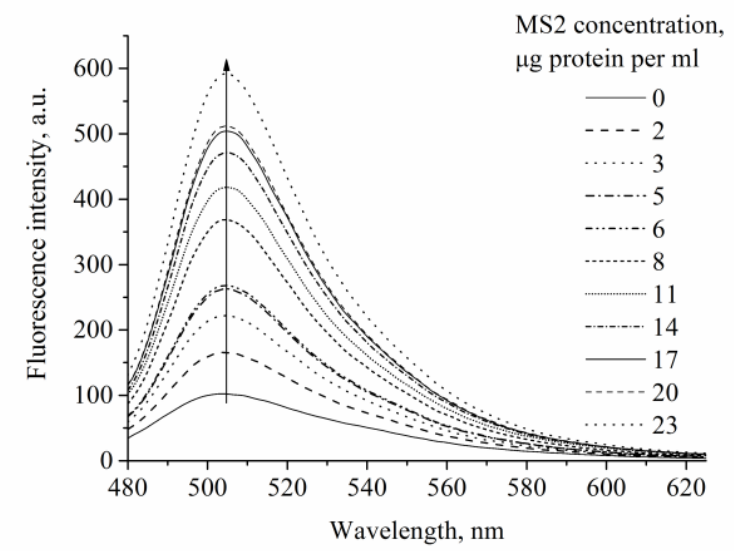

A

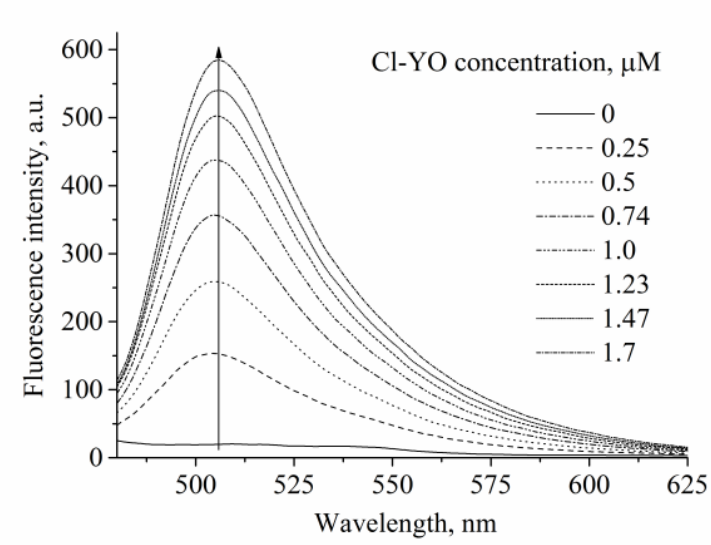

B

\section{Figure 2.}

Fluorescence spectra of $\mathrm{Cl}-\mathrm{YO}$ in the presence of $\mathrm{ms} 2 / \mathrm{s} 1$ : direct (A) and reverse (B) titrations. The dye and protein concentrations were $0.5 \mu \mathrm{M}$ and $5.3 \mu \mathrm{g}$ protein per ml, respectively.

The fluorescence data were used to build the Scatchard plots (Figure 3) and to determine the quantitative characteristics of the dye-MS2 complexation, as described in Section 2.9. The linear 
Scatchard plots were obtained for all fluorophores, except YO-Pent, indicating the existence of one binding mode [44].

As seen in Table 1, all cyanines showed comparable $F_{\text {mol }}$ values, except F-YO, that displayed the lowest fluorescence response to $\mathrm{ms} 2 / \mathrm{s} 1$ presumably due to the effects of fluorine substituent in the benzoxazole heterocycle on the spectral properties of the dye [56]. For example, the $\log P$ value of F-YO was 3 times smaller, than that of $\mathrm{Cl}-\mathrm{YO}$, that could account for the observed differences in the $F_{m o l}$ (although the quantum chemistry characteristics were similar for all dyes, Table S1). The association constants for the dye-MS2 binding were found to be comparable for the investigated compounds (showing slight increase for $\mathrm{Cl}-\mathrm{YO}-\mathrm{Bu}$ and $\mathrm{YO}-$ Pent), being close to that reported for the cationic monomethine cyanine dye T-284 binding to fibrillar $\alpha$-synuclein [57].

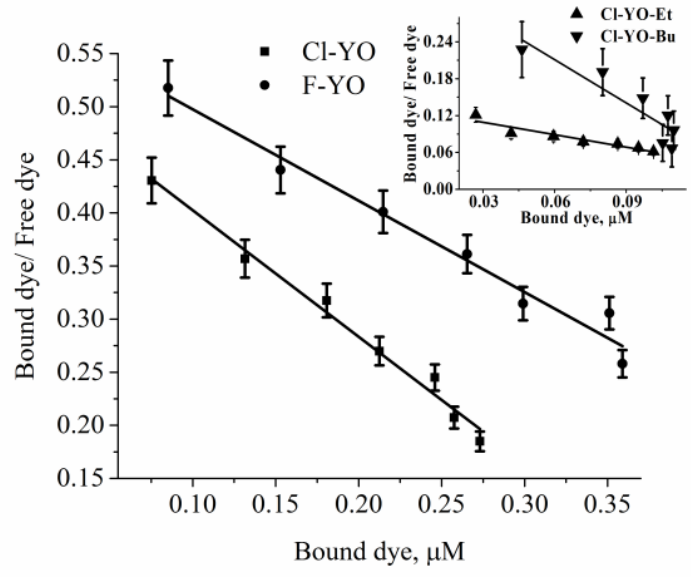

A

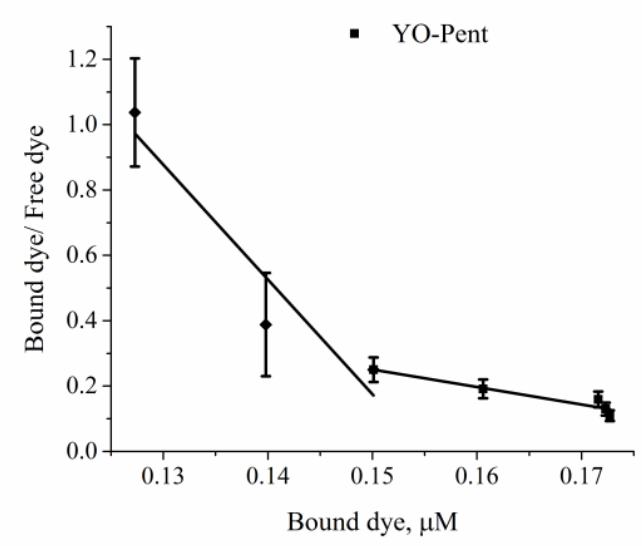

B

\section{Figure 3.}

Scatchard plots of the cyanine dyes in the presence of $\mathrm{ms} 2 / \mathrm{s} 1$ bacteriophage $(5.3 \mu \mathrm{g}$ protein per $\mathrm{ml})$.

As seen in Table 1, all cyanines showed comparable $F_{\text {mol }}$ values, except F-YO, that displayed the lowest fluorescence response to $\mathrm{ms} 2 / \mathrm{s} 1$ presumably due to the effects of fluorine substituent in the benzoxazole heterocycle on the spectral properties of the dye [56]. For example, the LogP value of F-YO was 3 times smaller, than that of $\mathrm{Cl}-\mathrm{YO}$, that could account for the observed differences in the $F_{m o l}$ (although the quantum chemistry characteristics were similar for all dyes, Table S1). The association constants for the dye MS2 binding were found to be comparable for the investigated compounds (showing slight increase for $\mathrm{Cl}$ YO $\mathrm{Bu}$ and $\mathrm{YO}$ Pent), being close to that reported for the cationic monomethine cyanine dye T 284 binding to 
fibrillar a synuclein [57]. To the best of our knowledge, there were no reports of quantitative characterization of the non-covalent binding of the small organic ligands to the bacteriophage MS2. Instead, much work has been aimed at evaluating the photo-induced inactivation and inhibition of bacteriophages [58-61], as well as studying their absorbance on different surfaces $[62,63]$. Interestingly, Yamamoto M. reported affinities of the dyes, including Methylene Blue, Acridine Orange, Crystal Violet, for the nucleic acids of the bacteriophage T5 $c a . \sim 0.3-3 \mu \mathrm{M}^{-1}$ [59], while the affinity of the MS2-binding protein for MS2 capsid was about $74 \mu \mathrm{M}^{-1}$ [64], and the association constant of the MS2 capsid binding to MS2 RNA was $\sim 333 \mu \mathrm{M}^{-1}$ [65]. Thus, our results, revealing the association constants $\sim 1 \mu \mathrm{M}^{-1}$ for the cyanine binding to $\mathrm{ms} 2 / \mathrm{s} 1$, are comparable with the affinity of the organic dyes for nucleic acids, and have lower specificity to MS2 capsid than that of proteins and nucleic acids.

Similarly to the classical non-covalent protein marker Nano Orange, the novel compounds appeared to detect MS2 in the very low concentration range, $c a$. $~ 2-20 \mathrm{nM}$ protein per $\mathrm{ml}$ [4]. In turn, the $n$ value decreased $\sim 3$ times when the length of the alkyl substituent on the quinoline heterocycle exceeded the methyl group length (Table 1). Thus, the steric hindrances may result in the decrement of the number of MS2 binding sites for Cl-YO-Et, Cl-YO-Bu and YO-Pent, possessing bulky alkyl substituents. On the other hand, the steric factors may promote the appearance of the second (highly specific) MS2 binding site for YO-Pent ( $K_{a 2}$, Table 1) presumably due to the enhanced van-der-Waals and hydrophobic dye-MS2 interactions, especially at a relatively high ionic strength $(\sim 0.15 \mathrm{M})$, when the intermolecular electrostatic interactions are partially screened (Table 1) [45,66]. For instance, Rhodamine B [29] and Sypro Orange [45] were reported to attach to the hydrophobic sites of the intact and partially denaturated (at $60{ }^{\circ} \mathrm{C}$ ) MS2 capsid. The above assumptions are also corroborated by simple docking studies (Section 2.9), providing the MS2 capsid binding sites for the cyanine dyes. A negatively charged external surface of the capsid attracts the cationic dyes [17], which may further accommodate in the low charge density sites, i.e., clefts, formed by the three $(2 \mathrm{~A} / \mathrm{B}, 1$ $\mathrm{C} / \mathrm{C})$ or two (A/B) neighbouring dimers of the capsid trimer and pentamer, respectively (Figures 4A, S6) [20]. The trimer cleft is presumably a specific MS2 binding site for the dyes because it is deep and has a greater number of neighbouring amino acid residues capable of interacting with small ligands [67]. In turn, theoretical possibility of the dye penetration through the MS2 pore (hypothesis 2) was also shown by molecular docking (Figures 4B, S7). 


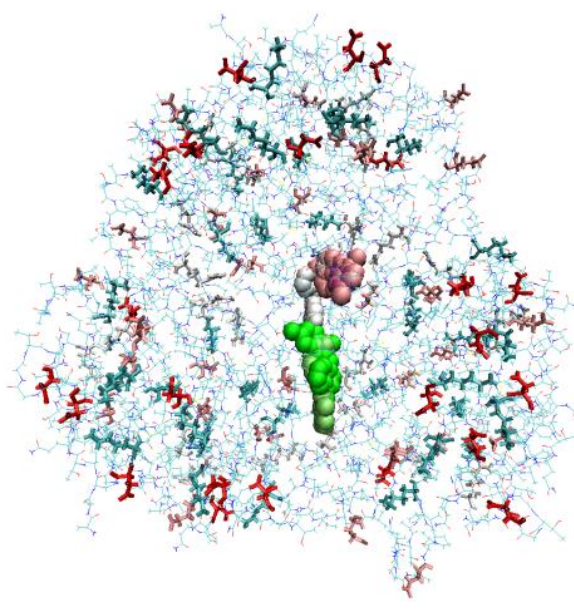

A

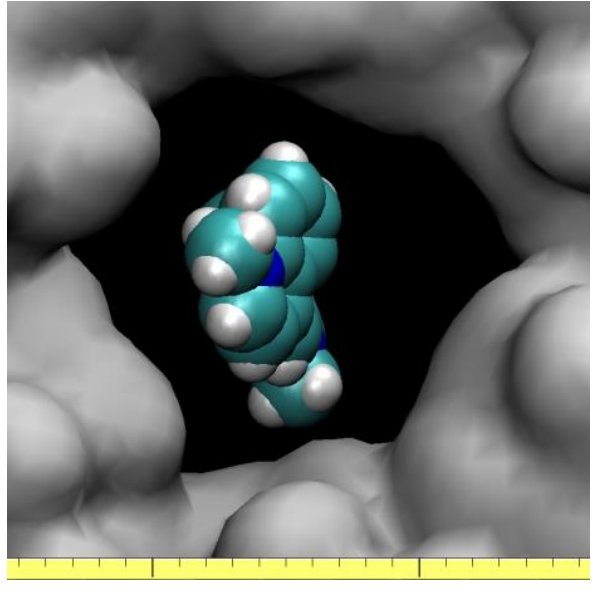

B

\section{Figure 4.}

Schematic representation of the energetically most favorable dye complexes with the cleft of the MS2 trimer (subunit, formed by the two A/B dimers and one C/C dimer) [20] (A), and geometric correspondence between the $\mathrm{Cl}-\mathrm{YO}$ size and the MS2 pentamer pore size (the model is taken from [17]) visualised by VMD software (B). Cl-YO, F-YO, Cl-YO-Et, Cl-YO-Bu, YO-Pent are coloured in green, white, pink, light-green, light-pink, respectively. Acidic and basic residues (Asp - red, Glu - pink, Lys - cyan, Arg - white) are represented in bonds (A). Cl-YO is shown as VDW spheres. The MS2 pentamer is represented as surface (grey), and the pore is colored in black. Scale is $0.1 \mathrm{~nm}(\mathrm{~B})$.

Interestingly, if we assume that the cyanines associate with the capsid exterior (hypothesis 1), MS2 (mole of particles)/ dye (mole) ratio would be $\sim 0.02$ and $\sim 0.0015$ for the direct and reverse titrations, respectively. Next, taking into account the fact that one MS2 particle has 60 clefts formed by three $(2 \mathrm{~A} / \mathrm{B}, 1 \mathrm{C} / \mathrm{C})$ dimers, $\sim 0.9$ and 11 dyes may theoretically associate with each capsid trimer under the conditions of direct and reverse titrations (at the final titration point), respectively [14]. However, the estimated dye/ MS2 ratios (Table 1, $n_{d p}$ ) when divided by 60 (total number of MS2 trimers) were $\sim 1-4.5$ (for the reverse titration). These estimates point to the incomplete binding of the cyanines to MS2 capsid. Notably, cyanine self-assembly on the MS2 scaffold is hardly possible (although it occurred in nucleic acids) because no shifts in the dye fluorescence spectra were observed in the presence of the phage (Figures 2, S3-S5) $[68,69]$.

\section{Table 1.}

Quantitative characteristics of the dye binding to MS2 bacteriophage

\begin{tabular}{|l|c|c|c|c|}
\hline Dye & $F_{m o l}, \times 10^{9} \mathrm{M}^{-1}$ & $K_{a}, \mu \mathrm{M}^{-1}$ & $n, \mu \mathrm{M} / \mathrm{mg}$ & $\begin{array}{c}n_{d p}, \text { dye } / \mathrm{MS} 2 \\
(\mathrm{M} / \mathrm{M})\end{array}$ \\
\hline
\end{tabular}




\begin{tabular}{|l|c|c|c|c|}
\hline Cl-YO & $1.4 \pm 0.3$ & $1.2 \pm 0.2$ & $0.08 \pm 0.02$ & $174 \pm 35$ \\
\hline F-YO & $0.7 \pm 0.1$ & $0.9 \pm 0.2$ & $0.13 \pm 0.03$ & $269 \pm 54$ \\
\hline Cl-YO-Et & $3.0 \pm 0.6$ & $0.7 \pm 0.1$ & $0.04 \pm 0.01$ & $76 \pm 15$ \\
\hline Cl-YO-Bu & $3.0 \pm 0.6$ & $2.4 \pm 0.5$ & $0.03 \pm 0.01$ & $59 \pm 12$ \\
\hline \multirow{2}{*}{ YO-Pent } & $1.8 \pm 0.4$ & $K_{a 1}=5.3 \pm 1.1$ & $n_{1}=0.04 \pm 0.01$ & $n_{d p 1}=78 \pm 16$ \\
& & $K_{a 2}=35 \pm 7$ & $n_{2}=0.03 \pm 0.01$ & $n_{d p 2}=61 \pm 12$ \\
\hline
\end{tabular}

Therefore, $3 \mathrm{Cl}-\mathrm{YO}$ or $\sim 5 \mathrm{~F}-\mathrm{YO}$ molecules are unlikely to form complexes with one MS2 trimer, although $n_{d p} / 60$ values for these dyes were 3 and 4.5 , respectively (Table 1). Thus, despite the linear Scatchard plots (Figure 3), one may also assume the presence of the secondary binding modes for Cl-YO- and F-YO-MS2, that is the dye binding between the two (A/B) neighbouring dimers of the capsid pentamer (Figure S6). In turn, Cl-YO-Et, Cl-YO-Bu, YOPent (possessing long alkyl substituents in the quinoline heterocycle) showed the lowest $n_{d p} / 60$ values of $\sim 1-1.3$, suggesting the binding of one dye molecule per the trimer cleft. Finally, the Scatchard plot of YO-Pent (Figure 3B) has a convex shape most probably arising from a negative binding cooperativity [70], since the calculated $K_{a 2}$ value (Table 1) seems to be incredibly high. It is also noteworthy that a negative cooperativity is unlikely to result from the YO-Pent-induced alterations in the capsid structure, because only penetration of the small molecules inside the phage followed by the RNA extension is believed to induce capsid destabilization [31].

By analogy with the calculations of the dye/MS2 capsid molar ratios, the ratio of the MS2 RNA nucleotide to the dye molar concentrations at the final titration point (reverse titration), were estimated as follows (hypothesis 2): i) the MS2 RNA concentration ( $\mathrm{mg} / \mathrm{ml}$ ) was calculated using the proportion: molecular weight $(\mathrm{MW})$ of MS2 capsid / MW of MS2 RNA = $2.1 \cdot 10^{6}(g / M) /\left[1.6 \cdot 10^{6}(g / M)\right] \approx 1.3 \rightarrow$ MS2 RNA concentration $=0.0053 \mathrm{mg}$ protein per $\mathrm{ml}$ (experimentally determined protein concentration, Section 2.3) / $1.3=0.004 \mathrm{mg} / \mathrm{ml}$ [12]; ii) the average molar weight of the MS2 RNA nucleotide is $339.5 \mathrm{~g} / \mathrm{M}$ [71], therefore, the MS2 RNA nucleotide concentration equals $\sim 12 \mu \mathrm{M}$; iii) P/D ratio $=12 / 1.7$ (dye concentration in the final titration point) $\sim 7$, pointing to enough space for the dye monomer binding to RNA without further dye self-association [50]. Analogously, the calculations for the direct titration (Figures 2A, S3) were performed, yielding the P/D ratio 90. Furthermore, the stoichiometry of the dye complexation with MS2 (Table 2) was converted from: $\mu \mathrm{M}$ (dye) / mg (protein) to: nucleotides / dye $(\mathrm{M} / \mathrm{M})$ (the number of the MS2 RNA nucleotides to the number of the bound dye 
molecules): $n_{R N A}($ nucleotides $/$ dye,$M / M)=3569 /\left[n(\mu M / m g) \cdot 2.1 \cdot 10^{6}(g / M)\right]$, where 3569 is a number of the MS2 RNA nucleotides [10]. Interestingly, the $n_{R N A}$ values obtained experimentally ( $c a$. $\sim 20-60$ ) were found to be significantly higher then 7 (a theoretically estimated P/D ratio at the final point of the reverse titration). This finding can be regarded as an argument in favour of the hypothesis 1 stating the preferential cyanine binding to the MS2 capsid [16,31]. Moreover, the unexpectedly high $n_{R N A}$ values are inconsistent with the high affinity constants of the YO dyes for MS2 (Table 2), as well as with previously reported selectivity of these species to the nucleic acids [50,72,73].

Nevertheless, the docking studies demonstrated the principal possibility for the cyanine binding to the MS2 RNA (hypothesis 2). Interestingly, YO-Pent, Cl-YO-Bu prefer the major groove of the RNA stem-loop, in contrast to the other dyes, associating with the minor groove (Figure S6C). Interestingly, the monomethine cyanines were reported to be the DNA intercalators $[31,74,75]$. Therefore, a highly efficient intercalative binding of these compounds to the MS2 ssRNA duplex, that is predominant at relatively high nucleotide to dye (P/D) ratios ( $4: 1$ - 10:1) [76,77], cannot be excluded [78]. However, at the ionic strength of $100-150 \mathrm{mM}$, exterior association of the cyanines to the DNA backbone was reported even at high P/D values [76]. It can be assumed that the dye binding to the RNA surface may occur due to the saltinduced (50 - $200 \mathrm{mM} \mathrm{NaCl})$ conformational changes in MS2 RNA, involving the decrease in the radius of gyration and strengthening of intramolecular hydrogen bonding [79]. Thus, the cyanines may have lower access to the RNA binding sites at high ionic strength due to steric restrictions in tightly coiled polynucleotide, allowing only the superficial RNA binding [79]. Interestingly, a geometric correspondence between the cyanine size and the MS2 pentamer pore size was shown, revealing that the investigated compounds can penetrate through the MS2 pentamer pore, mostly when the dye long axis is parallel to the pore axis (Figure S7), although the hydration shell of the fluorophore may hinder this process [17]. Thus, a fast penetration of the compounds under study in the MS2 interior seems to be is unlikely, and the observed rapid binding of the cyanines to $\mathrm{ms} 2 / \mathrm{s} 1$ can be attributed to the capsid ability to accommodate the dye molecules (Figure 1).

\subsection{Binding of the cyanine dyes to RNA and BSA}

To further substantiate the cyanine-MS2 binding mode, we compared the quantitative parameters for the dye interactions with a model protein (BSA) and ribonucleic acid (yeast RNA, composed of GC nucleotides similar to that of MS2 RNA) (Section 2.9). The representative titration spectra are shown in Figure 5, while the rest are in Figures S8-S9. 


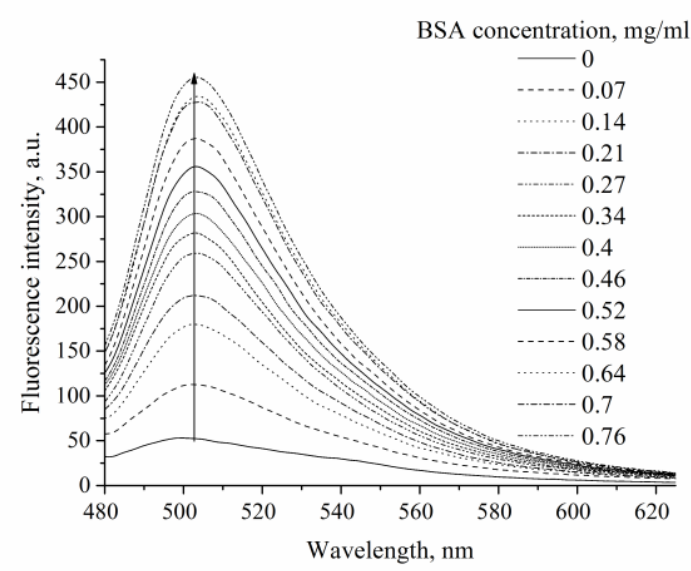

A

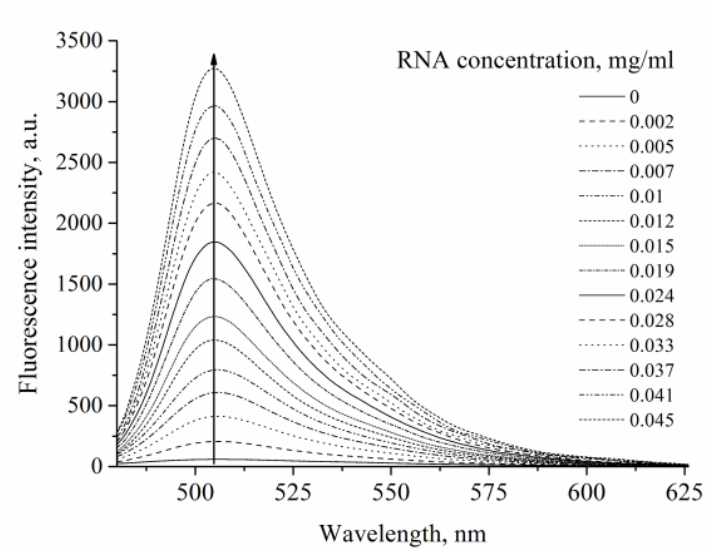

B

\section{Figure 5.}

Cl-YO fluorescence spectra measured in TRIS-MS2 buffer $(50 \mathrm{mM}, 150 \mathrm{mM} \mathrm{NaCl}, 5 \mathrm{mM}$ $\mathrm{CaCl}_{2}, 5 \mathrm{mM} \mathrm{MgCl}$ ) at increasing concentrations of bovine serum albumin (A) and yeast RNA (B). The dye concentration was $0.5 \mu \mathrm{M}$.

It appeared that the $F_{m o l}$ value $\left(\sim 1000 \mu \mathrm{M}^{-1}\right)$ for the Cl-YO-BSA complexation was comparable with that of the dye-ms2/s1 association (Table 1), suggesting that the dye-virus and the dye-BSA complexes are stabilized by similar non-covalent (electrostatic, steric, van-derWaals and hydrophobic) interactions [75]. In turn, the $F_{\text {mol }}$ estimates acquired for the cyanines and yeast RNA were one order of magnitude greater than those obtained for the MS2 phage (Table 2). These findings indirectly support the assumption of the dye complexation with the capsid (hypothesis 1).

Next, the linear Scatchard plots were obtained for the four yeast RNA-bound dyes (Figure S10), except YO-Pent (data not shown), and the recovered association constants were $1.3-6$ times greater than the corresponding values for the dye-MS2 binding (Table 2). Notably, the higher values of the association constants may result from the stronger electrostatic interactions between the dyes and RNA compared to the MS2 capsid (hypothesis 1).

In the following the ratio of yeast RNA to the dye molar concentration at the final titration point (P/D ratio) for the reverse titration was estimated (Figure S8), using the RNA concentration in the sample $41 \mu \mathrm{M}$ (the RNA amount in the stock solution, $1563 \mu \mathrm{M}$ nucleotides, was calculated based on the yeast RNA extinction coefficient at $260 \mathrm{~nm} 9250 \mathrm{M}^{-}$ ${ }^{1} \mathrm{~cm}^{-1}$ [80]), and the dye concentration in the final titration point $-2 \mu \mathrm{M}$. Remarkably, the obtained P/D ratio of $\sim 20$ suggests the intercalative binding mode of the dye monomers to yeast RNA [49]. Indeed, intercalation of the YO compounds between the DNA base pairs resulted in 
the restriction of the internal rotation followed by a significant enhancement of the fluorescence intensity, as compared to buffer [75]. Furthermore, high affinity of the examined cyanines for yeast RNA provides evidence for the dye intercalation between the RNA bases, because strong association of the structurally similar monomethines, YO-PRO-1 [76], 6-Cl-YO-1 [50], YO-PRO [31], with the nucleic acids was also reported at the high P/D ratios. For example, 6-Cl-YO-1 affinity for ds-RNA (poly A-poly $\mathrm{U}$ ) was estimated to be $\sim 10 \mu \mathrm{M}^{-1}$, although at low ionic strength $(50 \mathrm{mM})$ [50]. However, despite the above arguments in favour of the intercalative binding mode, the external dye binding to both yeast RNA and MS2 RNA (predominantly via the electrostatic interactions) may occur due to the structural changes of the nucleic acids at the ionic strength $150 \mathrm{mM}[79,81,82]$.

Table 2.

Quantitative characteristics of the dye binding to yeast RNA

\begin{tabular}{|l|c|c|c|c|}
\hline Dye & $F_{\text {mol }}, \times 10^{9} \mathrm{M}^{-1}$ & $K_{a}, \mu \mathrm{M}^{-1}$ & $n, \mu \mathrm{M} / \mathrm{mg}$ & $\begin{array}{c}n_{1}, \text { nucleotides/dye } \\
(\mathrm{M} / \mathrm{M})\end{array}$ \\
\hline Cl-YO & $30.6 \pm 6.1$ & $3.7 \pm 0.7$ & $0.004 \pm 0.001$ & $851 \pm 170$ \\
\hline F-YO & $17.3 \pm 3.5$ & $2.3 \pm 0.5$ & $0.004 \pm 0.001$ & $875 \pm 175$ \\
\hline Cl-YO-Et & $19.3 \pm 3.9$ & $3.9 \pm 0.8$ & $0.004 \pm 0.001$ & $788 \pm 158$ \\
\hline Cl-YO-Bu & $15.1 \pm 3.0$ & $3.2 \pm 0.6$ & $0.003 \pm 0.001$ & $926 \pm 185$ \\
\hline YO-Pent & $4.6 \pm 0.9$ & $\mathrm{n} / \mathrm{d}$ & $\mathrm{n} / \mathrm{d}$ & $\mathrm{n} / \mathrm{d}$ \\
\hline
\end{tabular}

The obtained $n$ values $(\mu \mathrm{M} / \mathrm{mg}$ ) were translated to nucleotides/dye (M/M) as described in Section 3.1, and represented in Table 2. The final formula was as follows: $n_{1}($ nucleotides / dye, $M / M)=\left[n(\mu M / m g) / 3154 \cdot 10^{-6}(M / g)\right]^{-1}$, where $3154 \cdot 10^{-6}$ is the number of RNA (nucleotide) moles in $1 \mathrm{~g}$ of yeast RNA. The $n_{1}$ values obtained for the yeast RNA appeared to be several times higher than those for MS2, further reinforcing the hypothesis 1 .

\subsection{Effect of heating on the dye association with MS2 bacteriophage}

Since the exposition of $\mathrm{ms} 2 / \mathrm{s} 2$ phage to $72{ }^{\circ} \mathrm{C}$ resulted in the capsid disruption, i.e., its disassembly and dimer denaturation, while the genome remained unchanged [24,45,79], a series of heating experiments (Section 2.9) was performed to check whether the cyanines have a stronger selectivity to the viral RNA as compared to the capsid surface. Notably, the kinetics of the dye binding to the $\mathrm{ms} 2 / \mathrm{s} 2$ was not significantly altered upon the protein denaturation as 
discussed in Section 3.1 (Figure 1), that allowed us to suggest the external association of the cyanines with MS2. As seen in Figure 6A, the heating of ms2/s2 induced a shift in tryptophan fluorescence maximum from $333 \mathrm{~nm}$ (close to that of the fully assembled capsid, $c a .327 \mathrm{~nm}$ ) to $354 \mathrm{~nm}$, revealing the coat protein denaturation [24]. Furthermore, the absorbance at $265 \mathrm{~nm}$ (the maximum similar to that of the viral RNA) [83] decreased by $~ 22 \%$ upon the ms $2 / \mathrm{s} 2$ heating, while the absorbance at $230 \mathrm{~nm}$ (reported to be very sensitive to the conformation of the tryptophan-rich polypeptides) completely disappeared confirming the coat protein unfolding

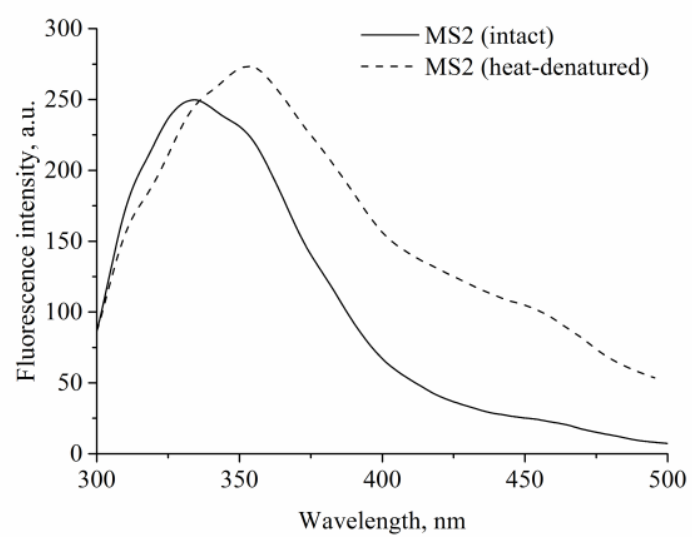

A

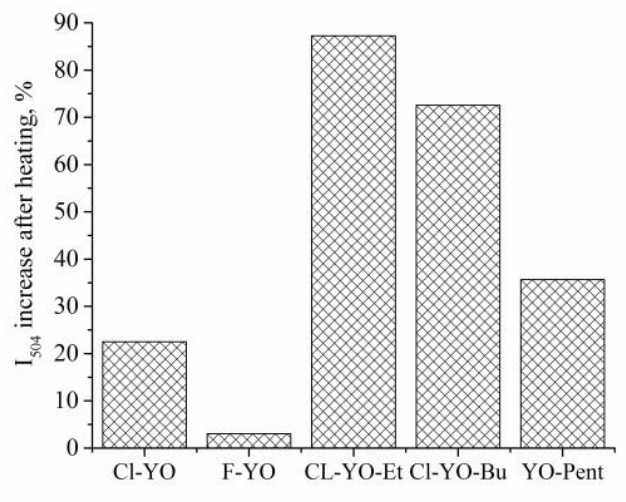

B

\section{Figure 6.}

Fluorescence spectra of the intact and heat-denatured ms $2 / \mathrm{s} 2\left(72^{\circ} \mathrm{C}, 20\right.$ minutes [45]) recorded in the TRIS-MS2 buffer $(50 \mathrm{mM}, 150 \mathrm{mM} \mathrm{NaCl}, 5 \mathrm{mM} \mathrm{CaCl} 2,5 \mathrm{mM} \mathrm{MgCl} 2)$. The $\mathrm{ms} 2 / \mathrm{s} 2$ concentration was $0.005 \mathrm{mg}$ protein per $\mathrm{ml}(\mathrm{A})$. Fluorescence intensity change (at $504 \mathrm{~nm}$ ) after MS2 heating. $\mathrm{ms} 2 / \mathrm{s} 2$ concentration was $0.06 \mathrm{mg}$ protein per $\mathrm{ml}$. The dye concentration was 0.5 $\mu \mathrm{M}$.

while the absorbance at $230 \mathrm{~nm}$ (reported to be very sensitive to the conformation of the tryptophan-rich polypeptides) completely disappeared confirming the coat protein unfolding (Figure S11) [84]. Interestingly, the absorbance of the capsid-free viral RNA increased by $10 \%$ upon heating to $72{ }^{\circ} \mathrm{C}$ [79], indicating that the phage absorbance decrease at 265 can be explained by the protein denaturation (Figure S11). Notably, in order to compare the above results for the intact and heat-denatured MS2, the measured absorption spectra were corrected for the sample turbidity [85].

Next, relative increase ( $c a .3-87 \%$ ) in the cyanine fluorescence intensity at the emission maxima $(\sim 504 \mathrm{~nm})$ was observed after the capsid disassembly, revealing the accessibility of the RNA binding sites to the dyes at high P/D ratio 90 (Figure 6B) [83]. Specifically, a substantial rise in the $\mathrm{Cl}-\mathrm{YO}-\mathrm{Et}, \mathrm{Cl}-\mathrm{YO}-\mathrm{Bu}$ and $\mathrm{YO}-\mathrm{Pent}$ fluorescence responses in the presence of thermally denatured ms $2 / \mathrm{s} 2$ may be provoked by the capsid disruption and subsequent dye 
association with the RNA surface. However, the spectral responses of Cl-YO-Et, Cl-YO-Bu and YO-Pent bound to the heat-denatured MS2 were lower than those of the yeast RNA-associated fluorophores (Table 2), revealing that the denatured capsid, but not the MS2 RNA, can essentially contribute to the observed effects [45]. It should also be emphasized that the interpretation of the above data is complicated by the possibility of the formation of large protein-RNA aggregates upon the phage heating, while the studies of the capsid-free genome [31] and the empty capsids [15,30] cannot be directly transferred to the behaviour of biologically active phage. Next, particles up to $100 \mathrm{~nm}$ in diameter were detected upon MS2 heating to $72{ }^{\circ} \mathrm{C}$ for 10 minutes [45], although the neat RNA did not aggregate in $0.15 \mathrm{M} \mathrm{NaCl}$ [79]. Furthermore, heating does not induce a complete detachment of the MS2 RNA, because of the strong affinity (hydrogen bonding) of the stem-loops to the coat protein [49,86,87]. Taking into account the above rationales, a moderate increase of $\mathrm{Cl}-\mathrm{YO}$ and $\mathrm{F}$-YO fluorescence after addition of the heat-denatured MS2 may be also due to the shortest lengths of the alkyl substituents on the quinoline heterocycle, resulting in the weaker affinity for the exposed hydrophobic patches of the capsid. Alternatively, one may suggest similar rigidity of the MS2 capsid and RNA binding sites resulting in the comparable fluorescence intensities of the cyanines in the intact and heatdenatured viruses.

\subsection{Effect of ribonuclease on the dye spectral properties in the presence of intact and heat-denatured MS2 phage}

As seen in Figure 7A, the ms2/s2-bound cyanines did not show any significant fluorescence response to the ribonuclease treatment (incubation for $5 \mathrm{~min}$ at room temperature) indicating that the RNA of the intact phage is not accessible to RNase [45]. Notably, a slight enhancement in the dye emission can be produced by the dye-enzyme binding (data not shown). In turn, the incubation of the dye-heat-denatured MS2 complexes in the presence of RNase (5 min at room temperature) resulted in the decrease of $\mathrm{Cl}-\mathrm{YO}$ and $\mathrm{F}-\mathrm{YO}$ fluorescence by $~ 55-60 \%$, providing strong evidence for the accessibility of the viral RNA to RNase after the particle disruption (Figure 7B) [45]. Thus, Cl-YO and F-YO seem to change their binding mode in the presence of heat-denatured $\mathrm{ms} 2 / \mathrm{s} 2$, in a way that $\sim 50 \%$ of the dyes become associated with the phage RNA. These compounds are likely to have similar fluorescence responses to the viral RNA and intact MS2, since no significant changes in the dye fluorescence were observed after the virus heating (Figure 6B). Since the RNase treatment combined with heating of MS2 was often employed to remove RNA from the phage [45,88], the retained fluorescence exceeding the background level is likely to result from the dye partial binding to the denatured capsid. 
Alternatively, the coat protein may hamper the RNA digestion by RNase $[49,86,89]$, the effect being enhanced by the formation of the protein-RNA aggregates at $72{ }^{\circ} \mathrm{C}$.

Small amounts of Cl-YO-Et, Cl-YO-Bu and YO-Pent may bind to RNA of the thermally disrupted phage, resulting in a slight sensitivity to RNase treatment $(\sim 7-30 \%$ fluorescence decrease) (Figure 7B). Indeed, a greater fluorescence enhancement of these dyes, possessing the long alkyl substituents in the quinoline heterocycle, in the heat-denatured phage, as compared to the intact MS2, suggests their preferential binding to the denatured MS2 capsid via hydrophobic interactions (Figure 6B). This assumption is corroborated by the fact that the MS2 hydrophobic domains are exposed to solvent upon heating and the charge of the capsid exterior becomes less negative [45]. In turn, steric hindrances may restrict $\mathrm{Cl}$ YO $\mathrm{Et}, \mathrm{Cl}$ YO $\mathrm{Bu}$

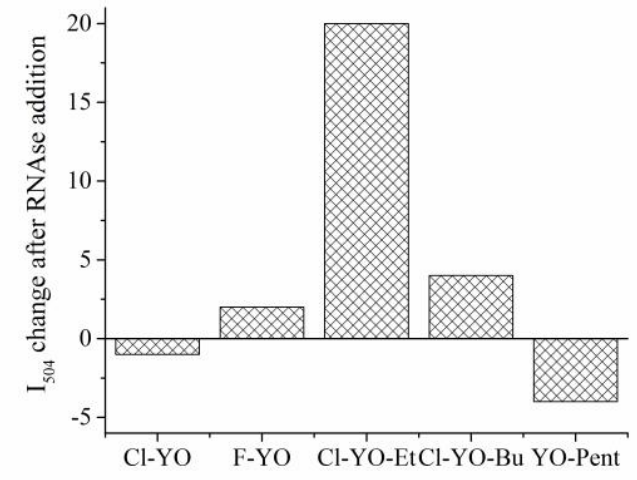

A

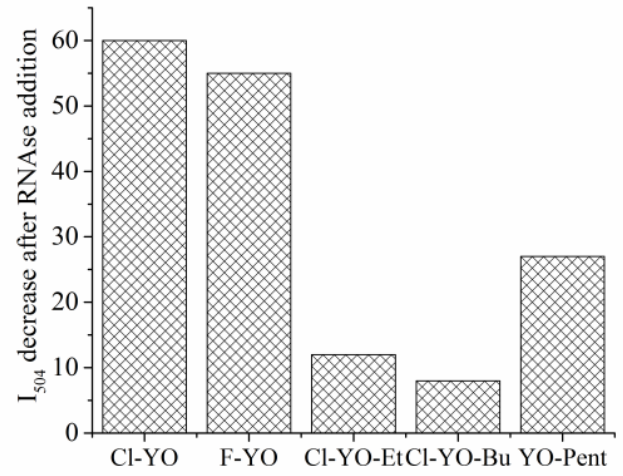

B

\section{Figure 7.}

RNase effect on the fluorescence of the dyes bound to the intact (A) and heat-denatured (B) $\mathrm{ms} 2 / \mathrm{s} 2 . \mathrm{ms} 2 / \mathrm{s} 2$ and dye concentrations were $0.06 \mathrm{mg}$ protein per $\mathrm{ml}$ and $0.5 \mu \mathrm{M}$, respectively. RNase concentration was $0.24 \mathrm{mg} / \mathrm{ml}$. The experiments were performed in TRIS-MS2 buffer (50 $\left.\mathrm{mM}, 150 \mathrm{mM} \mathrm{NaCl}, 5 \mathrm{mM} \mathrm{CaCl} 2,5 \mathrm{mM} \mathrm{MgCl}_{2}\right)$.

domains are exposed to solvent upon heating and the charge of the capsid exterior becomes less negative [45]. In turn, steric hindrances may restrict $\mathrm{Cl}-\mathrm{YO}-\mathrm{Et}, \mathrm{Cl}-\mathrm{YO}-\mathrm{Bu}$ and YO-Pent access to the viral RNA sites, as reported, e.g., for YO-PRO binding to the DNA of T5 bacteriophage [31]. Specifically, the observed effect resulted in a lower YO-PRO (possessing long hydrophobic tail) affinity for the densely packed T5 DNA than that of YO (without a hydrophobic tail) in $1 \mathrm{M}$ $\mathrm{NaCl}$ [31]. Alternatively, the low sensitivity of Cl-YO-Bu and YO-Pent to RNase treatment may be explained by the higher $K_{a}$ values of their association with RNA, resulting in the partial stabilization of the viral genome structure against its degradation by RNase (Table 1). Indeed, 
small molecules (both intercalators and groove binders) possessing high affinity for the nucleic acids were reported to exert such stabilizing effects [90-92]. However, this suggestion would be relevant for the investigated cyanines only if no restrictions were imposed on the dye binding to RNA of the heat-denatured phage that is hardly possible. Overall, the observed RNase effects provided additional evidence for the integrity of the studied MS2 particles, as well as revealed the predominant association of the dyes with the heat-denatured MS2 capsid via hydrophobic interactions, although about $50 \%$ of Cl-YO and F-YO strongly associated with the viral RNA. This can result from the formation of the coat protein-RNA aggregates upon the phage heating and significant restriction of the dye binding to the MS2 RNA.

\subsection{Sensitivity of the dyes to MS2 disruption by urea and guanidine hydrochloride}

Urea and $\mathrm{GdnHCl}$ have been widely employed to induce protein denaturation, including the virus stability studies [24,93-95]. In the present study these agents have been employed to further confirm the dye binding to MS2 capsid (hypothesis 1). As seen in Figure 8, the tryptophan fluorescence maxima of ms $2 / \mathrm{s} 2$ were at 358 and $351 \mathrm{~nm}$ in $4.2 \mathrm{M}$ urea and $3 \mathrm{M}$ $\mathrm{GdnHCl}$, respectively, revealing the coat protein unfolding [24]. Indeed, Lima and coworkers reported a substantial disruption of the MS2 shell in the presence of the above amounts of urea and $\mathrm{GdnHCl}$ [24]. The ms2/s2-bound Cl-YO was found to display 50 and $60 \%$ fluorescence decrease upon the addition of urea and $\mathrm{GdnHCl}$, respectively, revealing strong dye sensitivity to the capsid denaturation (Figure 9A). Indeed, $\mathrm{GdnHCl}$ is widely used for RNA extraction from, e.g., plant tissues [24,96], suggesting the RNA stability upon $\mathrm{GdnHCl}$ treatment. Furthermore, at low urea concentration $(0.44 \mathrm{M})$ that is not enough to induce significant alterations in the MS2 capsid structure [24], the fluorescence decrease from 9 to $22 \%$ was observed, suggesting the dye sensitivity to slight conformational changes of the capsid (Figure 9B). The spectral properties of the free cyanines in buffer were significantly altered by the denaturants, with the effect being more pronounced for $\mathrm{GdnHCl}$ (Figure 9). In view of this, the effect of denaturants on the capsid surface demonstrated with $\mathrm{Cl}-\mathrm{YO}$ can be underestimated due to the dye fluorescence enhancement in urea and $\mathrm{GdnHCl}$. Taken together, the above findings strongly support the hypothesis 1, because the viral RNA is not sensitive to urea and $\mathrm{GdnHCl}$ [24]. 


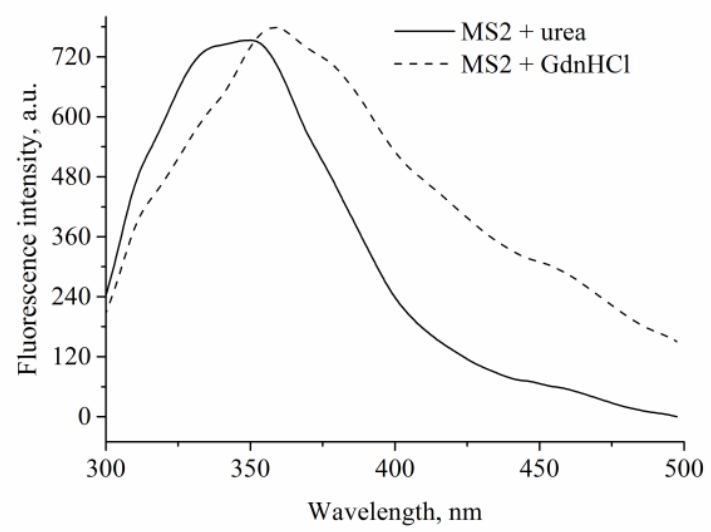

\section{Figure 8.}

Fluorescence spectra of ms2/s2 (0.06 mg protein per ml) denatured by urea (4.2 M) and $\mathrm{GdnHCl}$ (3 M). Incubation was performed for $16 \mathrm{hr}$ at room temperature. The phage intrinsic fluorescence was excited at $280 \mathrm{~nm}$.

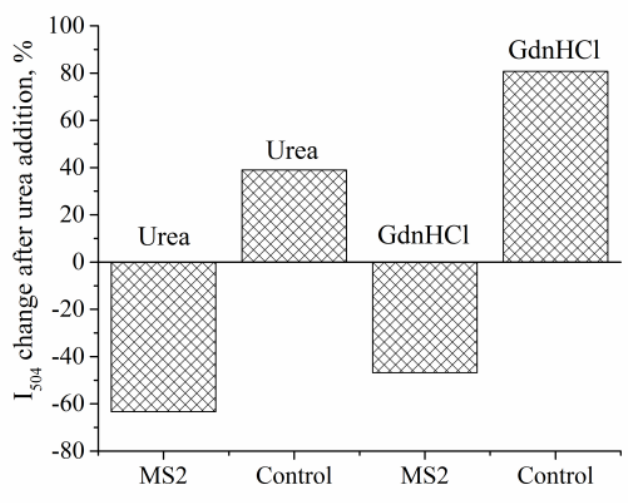

A

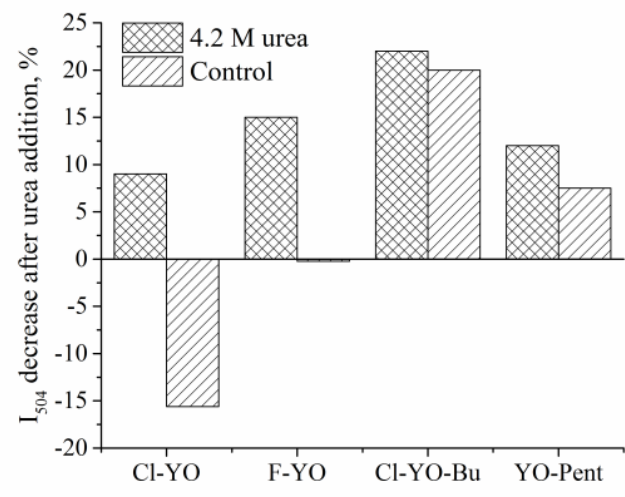

B

\section{Figure 9.}

Decrease in the fluorescence (at $504 \mathrm{~nm}$ ) of the MS2-bound Cl-YO in the presence of urea (4.2 $\mathrm{M})$ or guanidine hydrochloride $(3 \mathrm{M})$. The dye concentration was $0.5 \mu \mathrm{M}$, the $\mathrm{ms} 2 / \mathrm{s} 2$ concentration was $0.06 \mathrm{mg}$ protein per $\mathrm{ml}$. Control samples contained only $\mathrm{Cl}-\mathrm{YO}$ and urea/GdnHCl (A). Decrease in the fluorescence (at $504 \mathrm{~nm}$ ) of the MS2-bound dyes in the presence of urea $(0.44 \mathrm{M})$. The dye concentration was $2 \mu \mathrm{M}$, the $\mathrm{ms} 2 / \mathrm{s} 2$ concentration was 0.01 $\mathrm{mg}$ protein per $\mathrm{ml}(\mathrm{B})$. The experiments were performed in TRIS-MS2 buffer (50 mM, $150 \mathrm{mM}$ $\mathrm{NaCl}, 5 \mathrm{mM} \mathrm{CaCl} 2,5 \mathrm{mM} \mathrm{MgCl} 2$ ).

\section{7. $\quad \mathrm{NaCl}$ effects on the dye binding to MS2 phage}

The electrostatic interactions were reported to be predominant between the ms $2 / \mathrm{s} 2$ phage and the sorbent surfaces [5,63], induced inactivation, adhesion, and aggregation of the phage, and 
play a predominant role in the stabilization of the cationic cyanine dye-polynucleotide complexes $[31,97,98]$. In view of this, the last phase of the study was aimed at investigating the effects of ionic strength on the dye- ms $2 / \mathrm{s} 2$ binding. It appeared that the examined compounds bound to the phage show much lower fluorescence in TRIS-MS2 buffer, as compared to that in TRIS buffer $(10 \mathrm{mM})$, with the effect being more pronounced for the intact ms $2 / \mathrm{s} 2$ (Figure 10). These data support the predominant role of the electrostatic binding of the dyes to the viral capsid (hypothesis 1), despite MS2 exterior was reported to have many hydrophobic patches $[29,99]$.

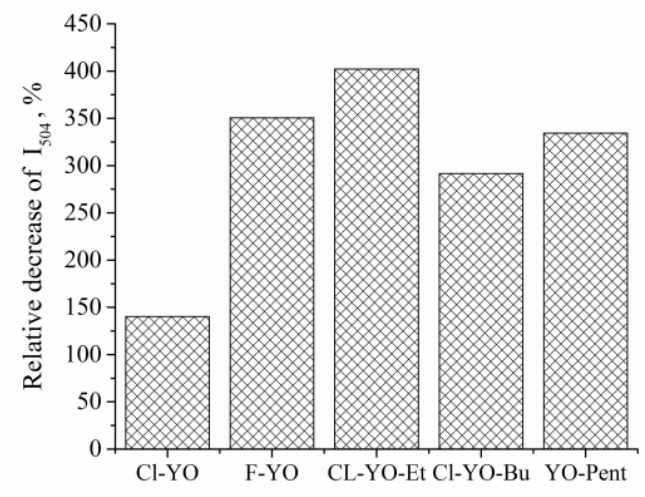

A

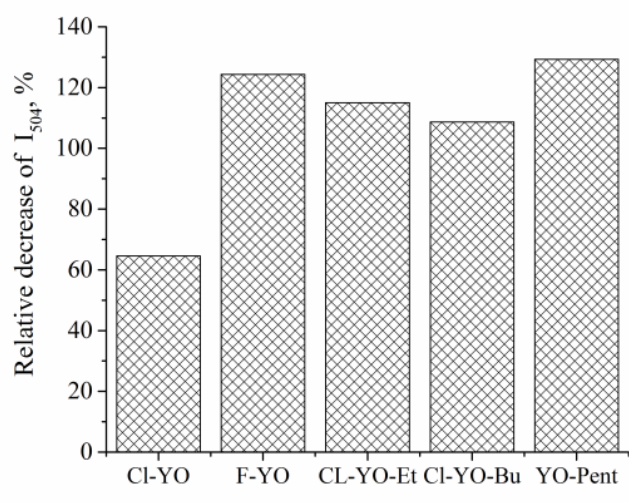

B

Figure 10.

Decrease in the fluorescence (at $504 \mathrm{~nm}$ ) of the dyes bound to the intact (A) and heat-denatured (B) $\mathrm{ms} 2 / \mathrm{s} 2$ in TRIS-MS2 buffer $\left(50 \mathrm{mM}, 150 \mathrm{mM} \mathrm{NaCl}, 5 \mathrm{mM} \mathrm{CaCl}_{2}, 5 \mathrm{mM} \mathrm{MgCl}_{2}\right.$ ) as compared to the phage-bound fluorophores in TRIS buffer $(10 \mathrm{mM})$. The $\mathrm{ms} 2 / \mathrm{s} 2$ concentration was $0.06 \mathrm{mg}$ protein per $\mathrm{ml}$.

Interestingly, the heat denaturation resulted in a partial screening of the dye-capsid electrostatic interactions, leading to a less significant effect of $\mathrm{NaCl}$ (Figure 10B). These results can be explained by the preferable dye binding to hydrophobic patches of the heat-denatured capsid, because the dye association with the viral RNA seems to be electrostatically driven [31]. Similarly, increased ionic strength resulted in the screening of the YO and YO-PRO affinities for the DNA of bacteriophage T5 [31].

Despite fluorescence intensity of the cyanines bound to the intact ms $2 / \mathrm{s} 2$ in TRIS buffer (10 $\mathrm{mM}$ ) was greater compared to that of the denatured phage, the opposite tendency was observed in TRIS-MS2 buffer (containing $0.15 \mathrm{M} \mathrm{NaCl}$ ), suggesting stronger contribution of other, most 
likely, hydrophobic dye-heat-denatured MS2 interactions to the stability of the complex (Figure 11).

In line with the results obtained by Eriksson and coworkers for the cyanine dyes binding to bacteriophage $\mathrm{T} 5,1 \mathrm{M} \mathrm{NaCl}$ was enough to screen the electrostatic interactions within the dyeheat-denatured MS2 complex, because the addition of salt induced similar fluorescence of the cyanines in TRIS (10 mM) and TRIS-MS2 buffers (Figure 11B) [31]. Furthermore, the measured fluorescence was only about two times higher than that of the free dyes in buffer, further confirming the predominant role of electrostatic interactions in the formation of the fluorophore-MS2 complexes.

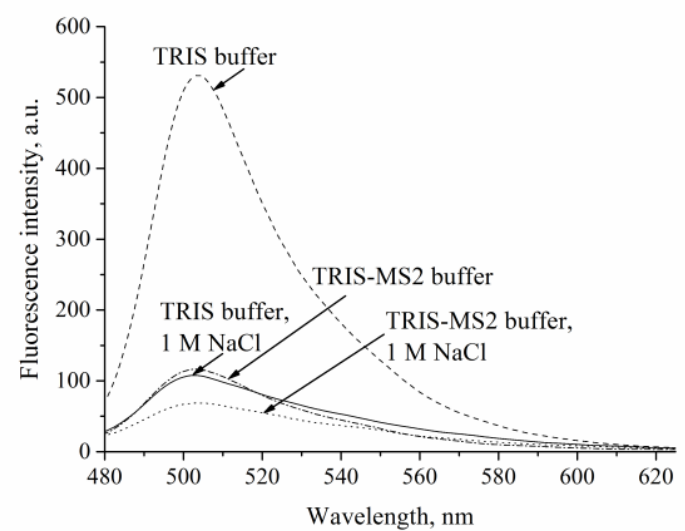

A

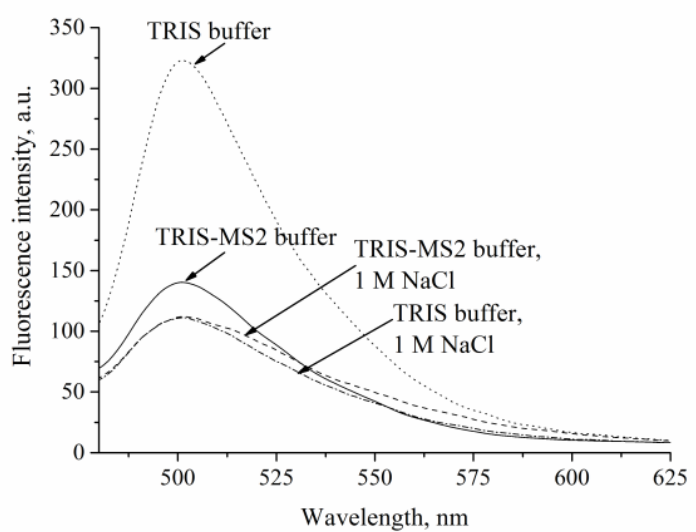

B

Figure 11.

Fluorescence spectra of YO-Pent bound to the intact (A) and heat-denatured (B) ms2/s2 in TRISMS2 (50 mM, $150 \mathrm{mM} \mathrm{NaCl}, 5 \mathrm{mM} \mathrm{CaCl}_{2}, 5 \mathrm{mM} \mathrm{MgCl}_{2}$ ) and in TRIS (10 mM) buffers, in the absence and presence of $\mathrm{NaCl}$. The $\mathrm{ms} 2 / \mathrm{s} 2$ concentration was $0.06 \mathrm{mg}$ protein per $\mathrm{ml}$.

Similar results were observed for the intact phage, although fluorescence of the dye in TRISMS2 buffer $(+1 \mathrm{M} \mathrm{NaCl})$ was $\sim 40 \%$ smaller than that in TRIS buffer $(10 \mathrm{mM},+1 \mathrm{M} \mathrm{NaCl})$, revealing stronger electrostatic interactions between the cyanine and intact MS2 (Figure 11A). Overall, the effects of $\mathrm{NaCl}$ on the cyanine binding to $\mathrm{ms} 2 / \mathrm{s} 2$, confirmed the predominant stabilisation of the dye-phage complexes by electrostatic interactions, especially for the intact MS2 at low ionic strength, although the role of hydrophobic forces increases in $0.15 \mathrm{M} \mathrm{NaCl}$.

\subsection{Binding of the dyes of different classes to MS2 phage}

Inspired by a strong affinity of the novel monomethine cyanine dyes to MS2 capsid and their sensitivity to the capsid stability, we also tested several classical (1,8-ANS, Thioflavin T, 
Acridine Orange, Methylene Blue) and novel (trimethine cyanine AK3-1 [100], phosphonium dye TDV) dyes for their ability to detect and characterize the phage. The fluorescence spectra of the dyes in buffer and in the presence of $\mathrm{ms} 2 / \mathrm{s} 1$ are shown in Figure S12. It appeared that Thioflavin T, AK3-1 and TDV display a moderate fluorescence response to the presence of MS2 (direct titration). For example, at the phage concentration $0.006 \mathrm{mg}$ protein per $\mathrm{ml}$, the dye fluorescence in the maxima increased by $60-80 \%$. Furthermore, the fluorescence enhancement of TDV was about 14-fold at $0.07 \mathrm{mg}$ protein per $\mathrm{ml}$, showing the potential of this dye as a sensitive MS2 marker. Notably, the observed fluorescence responses were lower as compared to those of the monomethine cyanine dyes (Figures 2A, S3). These findings reveal an impact of the steric dye-ms $2 / \mathrm{s} 2$ interactions on the fluorophore association with the capsid, because Thioflavin T, TDV and AK3-1 share common properties of the molecular rotors, showing the enhanced quantum yields upon the restriction of the internal rotation of the species bound to the macromolecules $[73,101,102]$. In turn, 1-anilinonaphthalene-8-sulfonic acid that is sensitive to the protein hydrophobicity, did not show any significant fluorescence response to ms2/s1 [103]. Next, Acridine Orange and Methylene Blue forming the stable complexes with DNA $[105,106]$ and proteins [104,105] via electrostatic and/or hydrophobic interactions did not show any spectral sensitivity to the presence of the phage (Figure S12). Fluorescence enhancement of the MS2 capsid-bound dyes would be observed if the above interactions were predominant $[106,107]$. Therefore, steric effects seem to play the major role in the binding of the MS2sensitive dyes to the phage capsid [74].

\subsection{Conclusions}

In conclusion, the present study proved the feasibility of using the novel monomethine cyanine dyes as non-covalent fluorescence markers of the MS2 bacteriophage. Despite simple and effective detection of viruses is of great demand, few studies addressing this topic have been reported $[4,31]$. Our results revealed significant fluorescence responses and micromolar affinities of the five YO derivatives for the MS2 phage in $0.15 \mathrm{M} \mathrm{NaCl}$, although they showed a sensitivity to yeast RNA and bovine serum albumin, as well. Similarly to the classical protein marker Nano Orange, the examined dyes were able to detect the MS2 phage in the very low concentration range $c a$. $\sim 2-20 \mathrm{nM}$ protein per $\mathrm{ml}$ [4]. The molecular docking, quantum chemistry calculations, kinetic, thermal and chemical denaturation studies pointed to the dye association with the MS2 capsid exterior via electrostatic, steric, van-der-Waals and hydrophobic interactions. It was found that up to $50 \%$ of the fluorophore molecules formed complexes with the viral RNA that became accessible for the cyanines after the capsid thermal disruption, although a significant fraction of the dyes were also bound to the denatured coat protein. The 
electrostatic cyanine-MS2 interactions were predominant at low ionic strength, while at physiological $\mathrm{NaCl}$ concentration the steric interactions seem to play prevalent role in the stabilisation of the dye-phage complexes. This conclusion was derived from the fact that among the classical and novel fluorophores tested in this study, only those sharing the properties of molecular rotors (including the YO compounds) exhibited noticeable fluorescence responses to the presence of MS2 phage. The obtained results can be employed for the development of highly specific fluorescence viral markers for biomedical applications.

\section{Acknowledgements}

This work was partly supported by the grants No 0119U002525, No 0119 U103453 and No 0117 U004966 from the Ministry of Education and Science of Ukraine. The research of ZB, DN and MS was supported by UK EPSRC grant AMR4AMR (EP/M02735X/1). We are grateful to Dr. S. Petrushenko, V. N. Karazin Kharkiv National University, for performing TEM measurements.

\section{Supplementary data}

Supplementary data associated with this article can be found in the online version at:

\section{References}

[1] I. Yildiz, S. Shukla, N.F. Steinmetz, Applications of viral nanoparticles in medicine, Curr. Opin. Biotechnol. 22 (2011) 901-908.

[2] E.D. Brown, Conformational constraints for amyloid fibrillation: the importance of being unfolded, Trends Biotechnol. 22 (2004) 434-436.

[3] W. Fiers, In Comprehensive Virology (Fraenkel-Conrat H \& Wagner RR, eds), (1979) pp. 69-204. Plenum, New York.

[4] Z. Liu, J. Pawliszyn, Behaviors of the MS2 virus and related antibodies in capillary isoelectric focusing with whole-column imaging detection, Electrophoresis. 26 (2005) $556-562$.

[5] A.J. Betancourt, Genomewide patterns of substitution in adaptively evolving populations of the RNA bacteriophage MS2, Genetics 181 (2009), 1535-1544.

[6] G.A. Shin, M.D. Sobsey, Reduction of Norwalk virus, poliovirus 1, and bacteriophage MS2 by ozone disinfection of water, Appl. Environ. Microbiol. 69 (2003) 3975-3978.

[7] M.R. Olson, R.P. Axler, R.E. Hicks, Effects of freezing and storage temperature on MS2 viability, J. Virol. Methods. 122 (2004) 147-152. 
[8] R. Aronino, C. Dlugy, E. Arkhangelsky, S. Shandalov, G. Oron, A. Brenner, V. Gitis, Removal of viruses from surface water and secondary effluents by sand filtration, Water Res. 43 (2009) 87-96.

[9] P. Gehringer, H. Eschweiler, H. Leth, W. Pribil, S. Pfleger, A. Cabaj, T. Haider, R. Sommer, Bacteriophages as viral indicators for radiation processing of water: a chemical approach, Appl. Radiat. Isot. 58 (2003) 651-656.

[10] R. Koning, S. van den Worm, J.R. Plaisier, J. van Duin, J. Pieter Abrahams, H. Koerten (2003) Visualization by cryo-electron microscopy of genomic RNA that binds to the protein capsid inside bacteriophage MS2. J Mol Biol 332:415-422.

[11] W. Fiers, R. Contreras, F. Duerinck, G. Haegeman, D. Iserentant, J. Merregaert, et al., Complete nucleotide sequence of bacteriophage MS2 RNA: primary and secondary structure of the replicase gene, Nature 260 (1976) 500-507.

[12] D.A. Kuzmanovic, I. Elashvili, C. Wick, C. O'Connell, S. Krueger, Bacteriophage MS2: molecular weight and spatial distribution of the protein and RNA components by smallangle neutron scattering and virus counting, Structure 11 (2003) 1339-1348.

[13] R.I. Koning, J. Gomez-Blanco, I. Akopjana, J. Vargas, A. Kazaks, K. Tars, J.M. Carazo, A.J. Koster, Asymmetric cryo-EM reconstruction of phage MS2 reveals genome structure in situ, Nat. Commun. 7 (2016) 12524.

[14] K. Toropova, G. Basnak, R. Twarock, P.G. Stockley, N.A. Ranson, The threedimensional structure of genomic RNA in bacteriophage MS2: implications for assembly, J. Mol. Biol. 375 (2008) 824-836.

[15] E.W. Kovacs, J.M. Hooker, D.W. Romanini, P.G. Holder, K.E. Berry, M.B. Francis, Dual-surface-modified bacteriophage MS2 as an ideal scaffold for a viral capsid-based drug delivery system, Bioconjug Chem 18 (2007) 1140-1147.

[16] J. Langlet, F. Gaboriaud, C. Gantzer, J.F. Duval, Impact of chemical and structural anisotropy on the electrophoretic mobility of spherical soft multilayer particles: the case of bacteriophage MS2, Biophys. J. 94 (2008) 3293-3312.

[17] V.S. Farafonov, D. Nerukh, MS2 bacteriophage capsid studied using all-atom molecular dynamics, Int. Focus. 9 (2019) 20180081.

[18] C. Dika, C. Gantzer, A. Perrin, J.F. Duval, Impact of the virus purification protocol on aggregation and electrokinetics of MS2 phages and corresponding virus-like particles, Phys. Chem. Chem. Phys. 15 (2013) 5691-5700.

[19] E. Tarasova, V. Farafonov, M. Taiji, D. Nerukh, Details of charge distribution in stable viral capsid, J. Mol. Liq. 265 (2018) 585-591. 
[20] Y. Fu, J. Li, A novel delivery platform based on Bacteriophage MS2 virus-like particles, Virus Res. 211 (2016) 9-16.

[21] S. Howorka, Molecular assembly in natural and engineered systems. Progress in molecular biology and translational science 103 (2011) 414 p.

[22] J.M. Hooker, E.W. Kovacs, M.B. Francis, Interior surface modification of bacteriophage MS2, J. Am. Chem. Soc. 126 (2004) 3718-3719.

[23] J. Krüse, B.J. Verduin, A.J. Visser, Intrinsic fluorescence of cowpea-chlorotic-mottlevirus protein, Eur. J. Biochem. 95 (1979) 21-29.

[24] S.M. Lima, A.C. Vaz, T.L. Souza, D.S. Peabody, J.L. Silva, A.C. Oliveira, Dissecting the role of protein-protein and protein-nucleic acid interactions in MS2 bacteriophage stability, FEBS J. 273 (2006) 1463-1475.

[25] P.A. Mosier-Boss, S.H. Lieberman, J.M. Andrews, F.L. Rohwer, L.E. Wegley, M. Breitbart, Use of fluorescently labeled phage in the detection and identification of bacterial species, Appl. Spectrosc. 57 (2003) 1138-1144.

[26] M. Asraf-Snir, V. Gitis, Tracer studies with fluorescent-dyed microorganisms - A new method for determination of residence time in chlorination reactors, Chem. Eng. J. 166 (2011) 579-585.

[27] C.M. Soto, A.S. Blum, G.J. Vora, N. Lebedev, C.E. Meador, A.P. Won, A. Chatterji, J.E. Johnson, B.R. Ratna, Fluorescent signal amplification of carbocyanine dyes using engineered viral nanoparticles, J. Am. Chem. Soc. 128 (2006) 5184-5189.

[28] K.L. Robertson, C.M. Soto, M.J. Archer, O. Odoemene, J.L. Liu, Engineered T4 viral nanoparticles for cellular imaging and flow cytometry, Bioconjug. Chem. 22 (2011) 595604.

[29] J.D. Lewis, G. Destito, A. Zijlstra, M.J. Gonzalez, J.P. Quigley, M. Manchester, H. Stuhlmann, Viral nanoparticles as tools for intravital vascular imaging, Nat. Med. 12 (2006) 354-360.

[30] N. Stephanopoulos, Z.M. Carrico, M.B. Francis, Nanoscale integration of sensitizing chromophores and porphyrins with bacteriophage MS2, Angew. Chem. Int. Ed. Engl. 48 (2009) 9498-9502.

[31] M. Eriksson, M. Härdelin, A. Larsson, J. Bergenholtz, B. Akerman, Binding of intercalating and groove-binding cyanine dyes to bacteriophage T5, J. Phys. Chem. B 111 (2007) 1139-1148.

[32] A. Kurutos, I. Balabanov, F.S. Kamounah, K. Nikolova-Ganeva, D. Borisova, N. Gadjev, T. Deligeorgiev, A. Tchorbanov, Bright green-emitting ds-DNA labeling employed by 
dicationic monomethine cyanine dyes: Apoptosis assay and fluorescent bio-imaging, Dyes and Pigments 157 (2018) 267-277.

[33] I.I. Timcheva, V.A. Maximova, T.G. Deligeorgiev, N.I. Gadjev, R.W. Sabnis, I.G. Ivanov, Fluorescence spectral characteristics of novel asymmetric monomethine cyanine dyes in nucleic acid solutions, FEBS Lett 405 (1997) 141-144.

[34] G. Patonay, J. Salon, J. Sowell, L. Strekowski, Noncovalent labeling of biomolecules with red and near-infrared dyes, Molecules 9 (2004) 40-49.

[35] S. Luo, E. Zhang, Y. Su, T. Cheng, C. Shi, A review of NIR dyes in cancer targeting and imaging, Biomaterials 32 (2011) 7127-7138.

[36] C. Shi, J.B. Wu, D. Pan, Review on near-infrared heptamethine cyanine dyes as theranostic agents for tumor imaging, targeting, and photodynamic therapy, J. Biomed. Opt. 21 (2016) 50901.

[37] K.D. Volkova, V.B. Kovalska, D. Inshin, Y.L. Slominskii, O.I. Tolmachev, S.M. Yarmoluk, Novel fluorescent trimethine cyanine dye 7519 for amyloid fibril inhibition assay, Biotech. Histochem. 86 (2011) 188-191.

[38] A. Fürstenberg, M.D. Julliard, T.G. Deligeorgiev, N.I. Gadjev, A.A. Vasilev, E. Vauthey, Ultrafast excited-state dynamics of DNA fluorescent intercalators: new insight into the fluorescence enhancement mechanism, J. Am. Chem. Soc. 128 (2005) 7661-7669.

[39] A. Brié, C. Gantzer, N. Boudaud, I. Bertrand, The impact of chlorine and heat on the infectivity and physicochemical properties of bacteriophage MS2, FEMS Microbiol Ecol 94 (2018) doi: 10.1093/femsec/fiy106.

[40] M.H. Adams, Bacteriophages, Interscience Publishers, New York, (1959) 592 p.

[41] J.H. Waterborg, H.R. Matthews, The Lowry method for protein quantitation, Methods Mol. Biol. 1 (1984) 1-3.

[42] H. LeVine, Thioflavine $\mathrm{T}$ interaction with synthetic Alzheimer's disease beta-amyloid peptides: Detection of amyloid aggregation in solution, Protein Sci 2 (1993) 404-410.

[43] K.D. Volkova, V.B. Kovalska, A.O. Balanda, M.Y. Losytskyy, A.G. Golub, R.J. Vermeij, V. Subramaniam, O.I. Tolmachev, S.M. Yarmoluk, Specific fluorescent detection of fibrillar $\alpha$-synuclein using mono- and trimethine cyanine dyes, Bioorg. Med. Chem. 16 (2008) 1452-1459.

[44] T. Bayraktutan, Y. Onganer, Spectral-luminescent study of coumarin 35 as fluorescent "light-up" probe for BSA and DNA monitoring, Dyes and Pigm. 142 (2017) 62-68.

[45] A. Brié, I. Bertrand, M. Meo, N. Boudaud, C. Gantzer, The effect of heat on the physicochemical properties of bacteriophage MS2, Food Environ. Virol. 8 (2016) 251261. 
[46] T.J. Hou, X.J. Xu, ADME evaluation in drug discovery. 3. Modeling blood-brain barrier partitioning using simple molecular descriptors, J. Chem. Inf. Comput. Sci. 43 (2003) 2137-2152.

[47] J.J.P. Stewart, Optimization of parameters for semiempirical methods v: Modification of NDDO approximations and application to 70 elements, J. Molecular Modelling 13 (2007) 1173-1213.

[48] D.E. Clark, Rapid calculation of polar molecular surface area and its application to the prediction of transport phenomena. 2. Prediction of blood-brain barrier penetration, J. Pharm. Sci. 88 (1999) 815-821.

[49] L. Poudel, R. Twarock, N.F. Steinmetz, R. Podgornik, W.Y. Ching, Impact of hydrogen bonding in the binding site between capsid protein and MS2 bacteriophage ssRNA, J. Phys. Chem. B 121 (2017) 6321-6330.

[50] A. Rožman, I. Crnolatac, T. Deligeorgiev, I. Piantanida, Strong impact of chloro substituent on TOTO and YOYO ds-DNA/RNA sensing, J. Luminesc. 205 (2019) 87-96.

[51] N.J. Gadjev, T.J. Deligeorgiev, S.H. Kim, Preparation of monomethine cyanine dyes as noncovalent labels for nucleic acids, Dyes Pigm. 40 (1999) 181-186.

[52] K. Vus, U. Tarabara, A. Kurutos, O. Ryzhova, G. Gorbenko, V. Trusova, N. Gadjev, T. Deligeorgiev, Aggregation behavior of novel heptamethine cyanine dyes upon their binding to native and fibrillar lysozyme, Mol. BioSyst. 13 (2017) 970-980.

[53] M. Wu, T. Sherwin, W.L. Brown, P.G. Stockley, Delivery of antisense oligonucleotides to leukemia cells by RNA bacteriophage capsids, Nanomedicine 1 (2005) 67-76.

[54] H. Majiya, O.O. Adeyemi, N.J. Stonehouse, P. Millner, Photodynamic inactivation of bacteriophage MS2: the A- protein is the target of virus inactivation. J. Photochem. Photobiol. B 178 (2018) 404-411.

[55] L.J. Jones, R.P. Haugland, V.L. Singer, Development and characterization of the NanoOrange protein quantitation assay: A fluorescence-based assay of proteins in solution, Biotechniques 34 (2003) 850-854.

[56] A. Kurutos, I. Balabanov, F.S. Kamounah, K. Nikolova-Ganeva, D. Borisova, N. Gadjev, T. Deligeorgiev, A. Tchorbanov, Bright green-emitting ds-DNA labeling employed by dicationic monomethine 1 cyanine 2 dyes: Apoptosis assay and fluorescent bio-imaging, Dyes and Pigm. 157 (2018) 267-277.

[57] K.D. Volkova, V.B. Kovalska, A.O. Balanda, M.Y. Losytskyy, A.G. Golub, R.J. Vermeij, V. Subramaniam, O.I. Tolmachev, S.M. Yarmoluk, Specific fluorescent detection of fibrillar a-synuclein using mono- and trimethine cyanine dyes, Bioorg. Med. Chem. 16 (2008) 1452-1459. 
[58] P. Amati, Photosensitivity of MS2 coliphage and its infective RNA after treatment with Acridine Orange. Virology. 33 (1967) 177-180.

[59] N. Yamamoto, Photodynamic inactivation of bacteriophage and its inhibition. J. Bacteriol. 75 (1958) 443-448.

[60] S. Jockusch, D. Lee, N.J. Turro, E.F. Leonard, Photo-induced inactivation of viruses: Adsorption of Methylene Blue, Thionine, and Thiopyronine on Qbeta bacteriophage. Proc. Natl. Acad. Sci. USA 93 (1996) 7446-7451.

[61] J.E. Jr. Schneider, T. Tabatabaie, L. Maidt, R.H. Smith, X. Nguyen, Q. Pye, R.A. Floyd, Potential mechanisms of photodynamic inactivation of virus by Methylene Blue 1. RNAprotein crosslinks and other oxidative lesions in $\mathrm{Q}$ beta bacteriophage. Photochem. Photobiol. 67 (1998) 350-357.

[62] Y. You, G.F. Vance, D.L. Sparks, J. Zhuang, Y. Jin, Sorption of MS2 Bacteriophage to layered double hydroxides: Effects of reaction time, $\mathrm{pH}$, and competing anions. J. Environ. Qual. 32 (2003) 2046-2053.

[63] A. Armanious, M. Aeppli, R. Jacak, D. Refardt, T. Sigstam, T. Kohn, M. Sander, Viruses at solid-water interfaces: A systematic assessment of interactions driving adsorption, Environ. Sci. Technol. 50 (2016) 732-743.

[64] M. Köhn, M. Lederer, K. Wächter, S. Hüttelmaier, Near-infrared (NIR) dye-labeled RNAs identify binding of ZBP1 to the noncoding Y3-RNA. RNA. 16 (2010) 1420-1428.

[65] S.S. Panchapakesan, S.C. Jeng, P.J. Unrau, RNA complex purification using high-affinity fluorescent RNA aptamer tags. Ann. N. Y. Acad. Sci. 1341 (2015) 149-155.

[66] C. Dika, J.F. Duval, G. Francius, A. Perrin, C. Gantzer, Isoelectric point is an inadequate descriptor of MS2, Phi X 174 and PRD1 phages adhesion on abiotic surfaces, J. Colloid Interface Sci. 446 (2015) 327-334.

[67] H. Kohita, Y. Matsushita, I. Moriguchi, Binding of carprofen to human and bovine serum albumins, Chem. Pharm. Bull (Tokyo) 42 (1994) 937-940.

[68] L. Glavas-Obrovac, I. Piantanida, S. Marczi, L. Masić, I.I. Timcheva, T.G. Deligeorgiev, Minor structural differences of monomethine cyanine derivatives yield strong variation in their interactions with DNA, RNA as well as on their in vitro antiproliferative activity, Bioorg. Med. Chem. 17 (2009) 4747-4755.

[69] T. Šmidlehner, A. Kurutos, J. Slade, R. Belužić, D.L. Ang, A. Rodger, I. Piantanida, Versatile click cyanine amino acid conjugates showing one- atom-influenced recognition of DNA/RNA secondary structure and mitochondrial localisation in living cells, Eur. J. Org. Chem. 2018 (2018) 1682-1692. 
[70] J. Hamacek, C. Piguet, How to adapt Scatchard plot for graphically addressing cooperativity in multicomponent self-assemblies, J. Phys. Chem. B 110 (2006) 77837792.

[71] R. Aranda 4th, S.M. Dineen, R.L. Craig, R.A. Guerrieri, J.M. Robertson, Comparison and evaluation of RNA quantification methods using viral, prokaryotic, and eukaryotic RNA over a 104 concentration range, Anal. Biochem. 387 (2009) 122-127.

[72] K. Uno, T. Sasaki, N. Sugimoto, H. Ito, T. Nishihara, S. Hagihara, T. Higashiyama, N. Sasaki, Y. Sato, K. Itami, Key structural elements of unsymmetrical cyanine dyes for highly sensitive fluorescence turn-on DNA probe, Chem. Asian. J. 12 (2017) 233-238.

[73] C. Carlsson, A. Larsson, M. Jonsson, B. Albinsson, B. Norden, Optical and photophysical properties of the Oxazole Yellow DNA probes YO and YOYO, J. Phys. Chem. 98 (1994) 10313-10321.

[74] A. Kurutos, O. Ryzhova, V. Trusova, U. Tarabara, G. Gorbenko, N. Gadjev, T. Deligeorgiev, Novel asymmetric monomethine cyanine dyes derived from sulfobetaine benzothiazolium moiety as potential fluorescent dyes for non-covalent labeling of DNA, Dyes and Pigm. 130 (2016) 122-128.

[75] M. Thompson, Synthesis, photophysical effects, and DNA targeting properties of Oxazole Yellow-peptide bioconjugates, Bioconjug. Chem. 17 (2006) 507-513.

[76] J.T. Petty, J.A. Bordelon, M.E. Robertson, Thermodynamic characterization of the association of cyanine dyes with DNA, J. Phys. Chem. B 104 (2000) 7221-7227.

[77] A. Larsson, C. Carlsson, M. Jonsson, B. Albinsson, Characterization of the binding of the fluorescent dyes YO and YOYO to DNA by polarized light spectroscopy, J. Am. Chem. Soc. 116 (1994) 8459-8465.

[78] C.D. Kanakis, P.A. Tarantilis, M.G. Polissiou, H.A. Tajmir-Riahi, Interaction of antioxidant flavonoids with tRNA: Intercalation or external binding and comparison with flavonoid-DNA adducts; Physics of RNA and viral assembly, DNA Cell Biol 25 (2006) 116-123.

[79] J.J. Strauss, R.L. Sinsheimer, Purification and properties of bacteriophage MS2 and of its ribonucleic acid, J. Mol. Biol. 7 (1963) 43-54.

[80] F. Abassi Joozdani, F. Yari, P. Abassi Joozdani, S. Nafisi, Interaction of Sulforaphane with DNA and RNA, PLoS One 10 (2015) e0127541.

[81] C.C. Hsieh, A. Balducci, P.S. Doyle, Ionic effects on the equilibrium dynamics of DNA confined in nanoslits, Nano Lett. 8 (2008) 1683-1688. 
[82] A. Zinchenko, DNA conformational behavior and compaction in biomimetic systems: Toward better understanding of DNA packaging in cell, Adv. Colloid Interface Sci. 232 (2016) 70-79.

[83] H.R. Johnson, J.M. Hooker, M.B. Francis, D.S. Clark, Solubilization and stabilization of bacteriophage MS2 in organic solvents, Biotechnol. Bioeng. 97 (2007) 224-234.

[84] P.F. Liu, L.V. Avramova, C. Park, Revisiting absorbance at $230 \mathrm{~nm}$ as a protein unfolding probe, Anal. Biochem. 389 (2009) 165-170.

[85] J. Fog, Turbidity in photometry. Correction for turbidity in photometric methods, The Analyst. 77 (1952) 918.

[86] S.S. Panchapakesan, S.C. Jeng, P.J. Unrau, RNA complex purification using high-affinity fluorescent RNA aptamer tags, Ann. N. Y. Acad. Sci. 1341 (2015) 149-155.

[87] E.V. Dolgosheina, P.J. Unrau, Fluorophore-binding RNA aptamers and their applications, Wiley Interdiscip. Rev. RNA 7 (2016) 843-851.

[88] P. Mikel, P. Vasickova, R. Tesarik, H. Malenovska, P. Kulich, T. Vesely, P. Kralik, Preparation of MS2 phage-like particles and their use as potential process control viruses for detection and quantification of enteric RNA viruses in different matrices, Front Microbiol. 7 (2016) 1911.

[89] S. Chattopadhyay, J. Garcia-Mena, J. DeVito, K. Wolska, A. Das, Bipartite function of a small RNA hairpin in transcription antitermination in bacteriophage lambda, Proc. Natl. Acad. Sci. USA 92 (1995) 4061-4065.

[90] A. Kurutos, I. Orehovec, A.T. Paić, I. Crnolatac, L. Horvat, N. Gadjev, I. Piantanida, T. Deligeorgiev, New series of non-toxic DNA intercalators, mitochondria targeting fluorescent dyes, Dyes and Pigm. 148 (2018) 452-459.

[91] M.M. Islam, P. Pandya, S.R. Chowdhury, S. Kumar, G.S. Kumar, Binding of DNAbinding alkaloids berberine and palmatine to tRNA and comparison to ethidium: Spectroscopic and molecular modeling studies, J. Mol. Struct. 891 (2008) 498-507.

[92] J. Kapuscinski, Z. Darzynkiewicz, M.R. Melamed, Interactions of acridine orange with nucleic acids, Biochem. Pharmacol. 32 (1983) 3679-3694.

[93] R.F.J. Greene, C.N. Pace, Urea and guanidine hydrochloride denaturation of ribonuclease, lysozyme, $\alpha$-chymotrypsin, and $\beta$-lactoglobulin, J. Biol. Chem. 249 (1974) $5388-5393$.

[94] O.D. Monera, C.M. Kay, R.S. Hodges, Protein denaturation with guanidine hydrochloride or urea provides a different estimate of stability depending on the contributions of electrostatic interactions, Protein Sci 3 (1994) 1984-1991. 
[95] R. O'Callaghan, R. Bradley, W. Paranchych, Controlled alterations in the physical and biological properties of R17 bacteriophage induced by guanidine hydrochloride, Virology 54 (1973) 476-494.

[96] M. Portillo, C. Fenoll, C. Escobar, Evaluation of different RNA extraction methods for small quantities of plant tissue: Combined effects of reagent type and homogenization procedure on RNA quality-integrity and yield, Physiologia Plantarum. 128 (2006) 1-7.

[97] J.M. Besterman, L.P. Elwell, S.G. Blanchard, M. Cory, Amiloride intercalates into DNA and inhibits DNA topoisomerase, J. Biol. Chem. 262 (1987) 13352-13358.

[98] S.M. Yarmoluk, S.S. Lukashov, M.Y. Losytskyy, B. Akerman, O.S. Kornyushyna, Interaction of cyanine dyes with nucleic acids XXVI. Intercalation of the trimethine cyanine dye Cyan 2 into double-stranded DNA: study by spectral luminescence methods, Spectrochim Acta A Mol Biomol Spectrosc 58 (2002) 3223-3232.

[99] C.L. Heldt, A. Zahid, K.S. Vijayaragavan, X. Mi, Experimental and computational surface hydrophobicity analysis of a non-enveloped virus and proteins, Colloids Surf B Biointerfaces 153 (2017) 77-84.

[100] K. Vus, M. Girych, V. Trusova, G. Gorbenko, A. Kurutos, A. Vasilev, N. Gadjev, T. Deligeorgiev, Cyanine dyes derived inhibition of insulin fibrillization, J. Mol. Liq. 276 (2019) 541-552.

[101] V.I. Stsiapura, A.A. Maskevich, V.A. Kuzmitsky, V.N. Uversky, I.M. Kuznetsova, K.K. Turoverov, Extrinsic Fluorescent dyes as tools for protein characterization 12 (2008) 15893-15902.

[102] M.A. Haidekker, M. Nipper, A. Mustafic, D. Lichlyter, M. Dakanali, E.A. Theodorakis, Dyes with segmental mobility: molecular rotors, in: Demchenko AP (Ed), Advanced fluorescence reporters in chemistry and biology I: Fundamentals and molecular design 8 (2010) 267-308.

[103] A. Hawe, M. Sutter, W. Jiskoot, Extrinsic Fluorescent dyes as tools for protein characterization, Pharm. Res. 25 (2008) 1487-1499.

[104] J. Kapuscinski, Z. Darzynkiewicz, Denaturation of nucleic acids induced by intercalating agents. Biochemical and biophysical properties of Acridine Orange-DNA complexes, J. Biomol. Struct. Dyn. 1 (1984) 1485-1499.

[105] R. Rohs, H. Sklenar, Methylene Blue binding to DNA with alternating AT base sequence: Minor groove binding is favored over intercalation, J. Biomol. Struct. Dyn. 21 (2004) 699-711. 
[106] G. Zhang, S. Shuang, C. Dong, J. Pan, Study on the interaction of Methylene Blue with cyclodextrin derivatives by absorption and fluorescence spectroscopy, Spectrochim. Acta Part A: Mol. and Biomol. Spectrosc. 59 (2003) 2935-2941.

[107] F. Wang, J. Yang, X. Wu, X. Wang, L. Feng, Z. Jia, C. Guo, Study on the formation and depolymerization of Acridine Orange dimer in Acridine Orange-sodium dodecyl benzene sulfonate-protein system, J. Colloid Interface Sci. 298 (2006) 757-764. 


\section{Supplementary data}

\section{Transmission electron microscopy}

For the electron microscopy assay, a $5 \mu 1$ drop of $\mathrm{ms} 2 / \mathrm{s} 1$ solution $(0.64 \mathrm{mg}$ protein per $\mathrm{ml})$ in TRIS buffer ( $\mathrm{pH} 7.5,50 \mathrm{mM}, 150 \mathrm{mM} \mathrm{NaCl}, 5 \mathrm{mM} \mathrm{CaCl} 2,5 \mathrm{mM} \mathrm{MgCl}_{2}$ ) was applied to a carbon-coated grid and blotted after $3 \mathrm{~min}$. A $10 \mu \mathrm{l}$ drop of $1.5 \%(\mathrm{w} / \mathrm{v})$ phosphotungstic acid solution was placed on the grid, blotted after $30 \mathrm{~s}$, and then washed 2 times by deionized water and air dried. The resulting grids were viewed by EM-125 electron microscope (Selmi, Ukraine) at $75 \mathrm{kV}$ (Figure S1A).

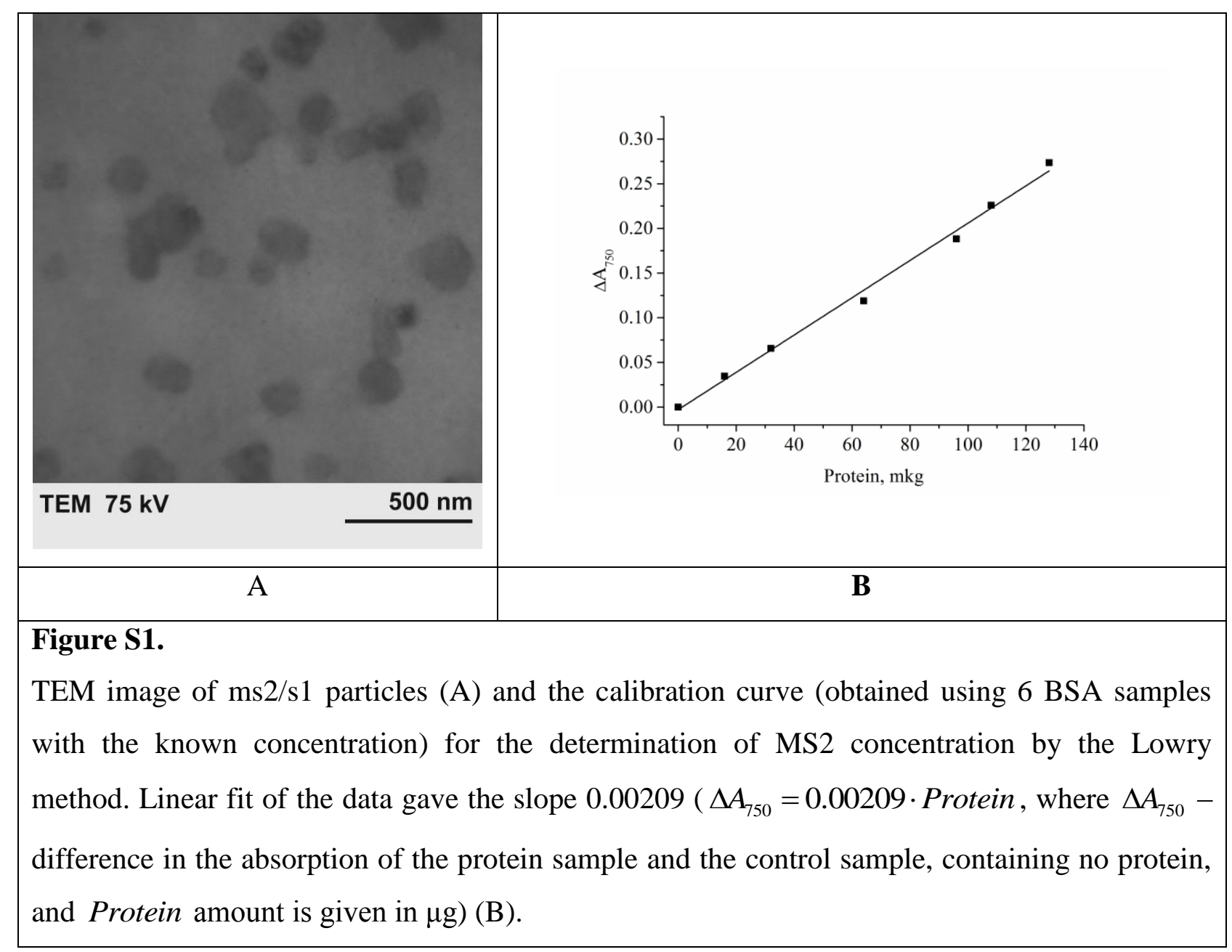




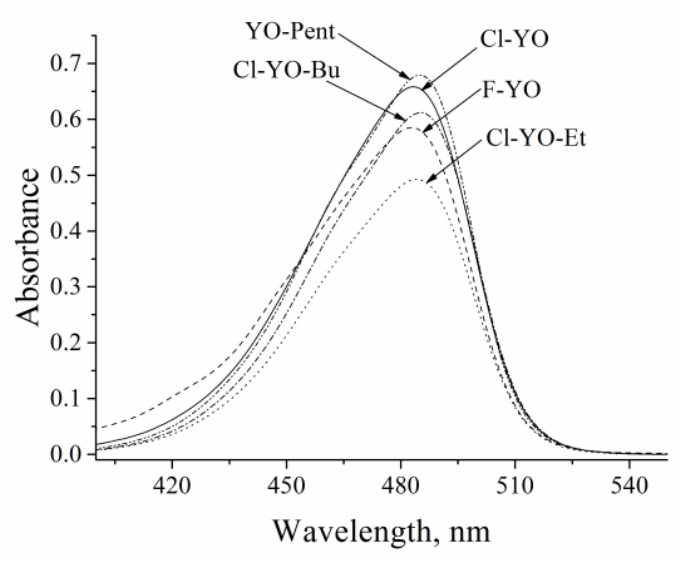

Figure S2.

Absorption spectra of the monomethine cyanine dyes in dimethyl sulfoxide.

Table S1

Quantum-chemical characteristics of cyanine dyes

\begin{tabular}{|c|c|c|c|c|c|c|c|c|c|}
\hline Dye & $\begin{array}{c}C A, \\
\AA^{2}\end{array}$ & $\begin{array}{l}C V, \\
\AA^{3}\end{array}$ & $\begin{array}{c}E_{\text {номо }}, \\
\mathrm{eV}\end{array}$ & $\begin{array}{c}E_{\text {LUMO }}, \\
\mathrm{eV}\end{array}$ & $L, \AA$ & $\begin{array}{c}W, \\
\AA\end{array}$ & $\begin{array}{c}H, \\
\AA\end{array}$ & $\begin{array}{c}\text { M. } \\
\text { wt., } \\
\text { g/M }\end{array}$ & $\log P$ \\
\hline $\mathrm{Cl}-\mathrm{YO}$ & 333 & 373 & -11.4 & -4.5 & 12.6 & 8.3 & 4.0 & 323.8 & 0.78 \\
\hline F-YO & 322 & 359 & -11.4 & -4.5 & 12.6 & 8.3 & 3.9 & 307.3 & 0.26 \\
\hline Cl-YO-Et & 350 & 395 & -11.3 & -4.5 & 13.9 & 7.8 & 3.9 & 337.8 & 1.15 \\
\hline $\begin{array}{l}\text { Cl-YO- } \\
\mathrm{Bu}\end{array}$ & 379 & 438 & -11.3 & -4.5 & 14.6 & 7.2 & 5.4 & 365.9 & 2.21 \\
\hline YO-Pent & 378 & 437 & -11.3 & -4.4 & 15.7 & 7.3 & 4.9 & 345.5 & 2.06 \\
\hline
\end{tabular}




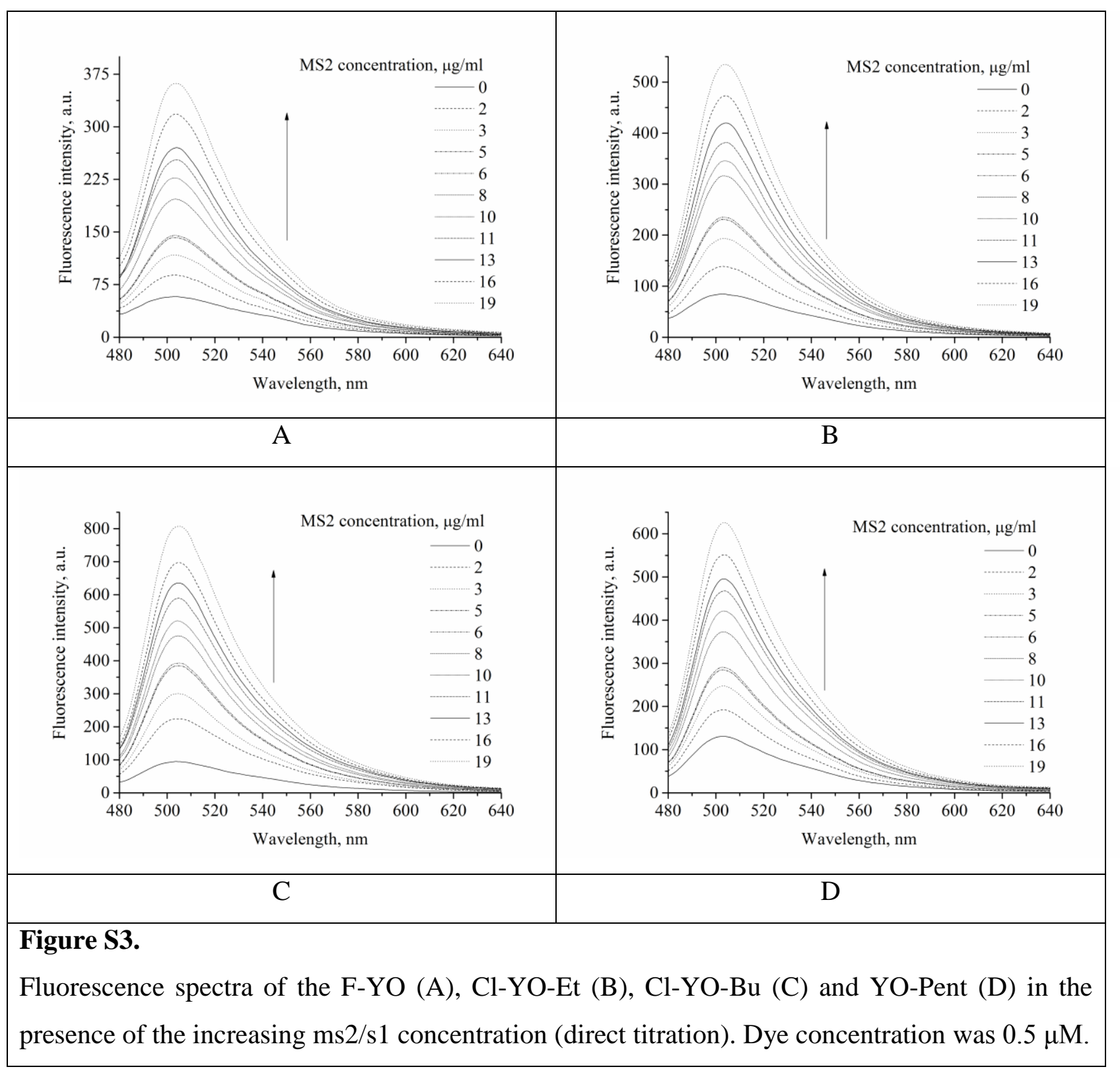




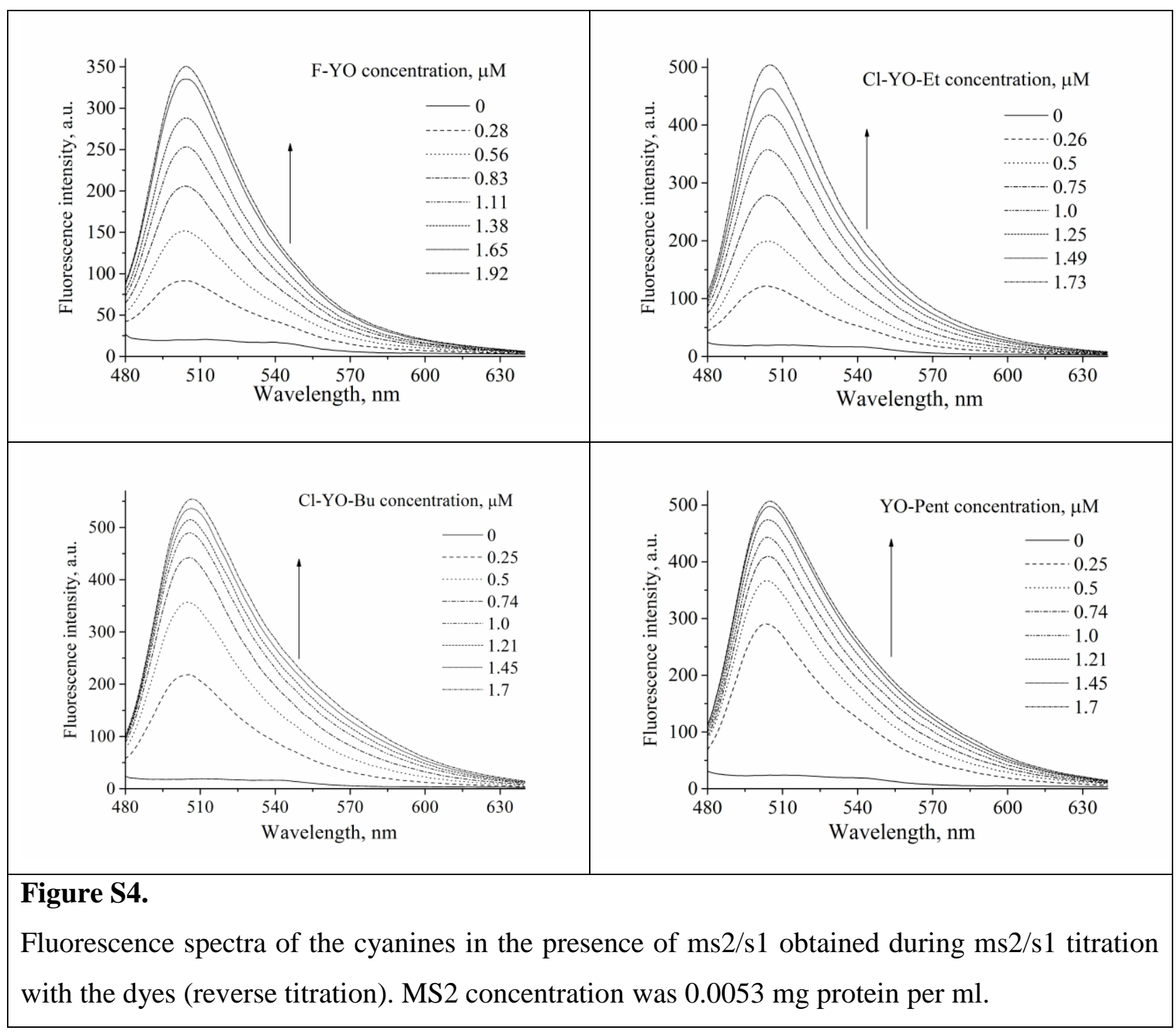




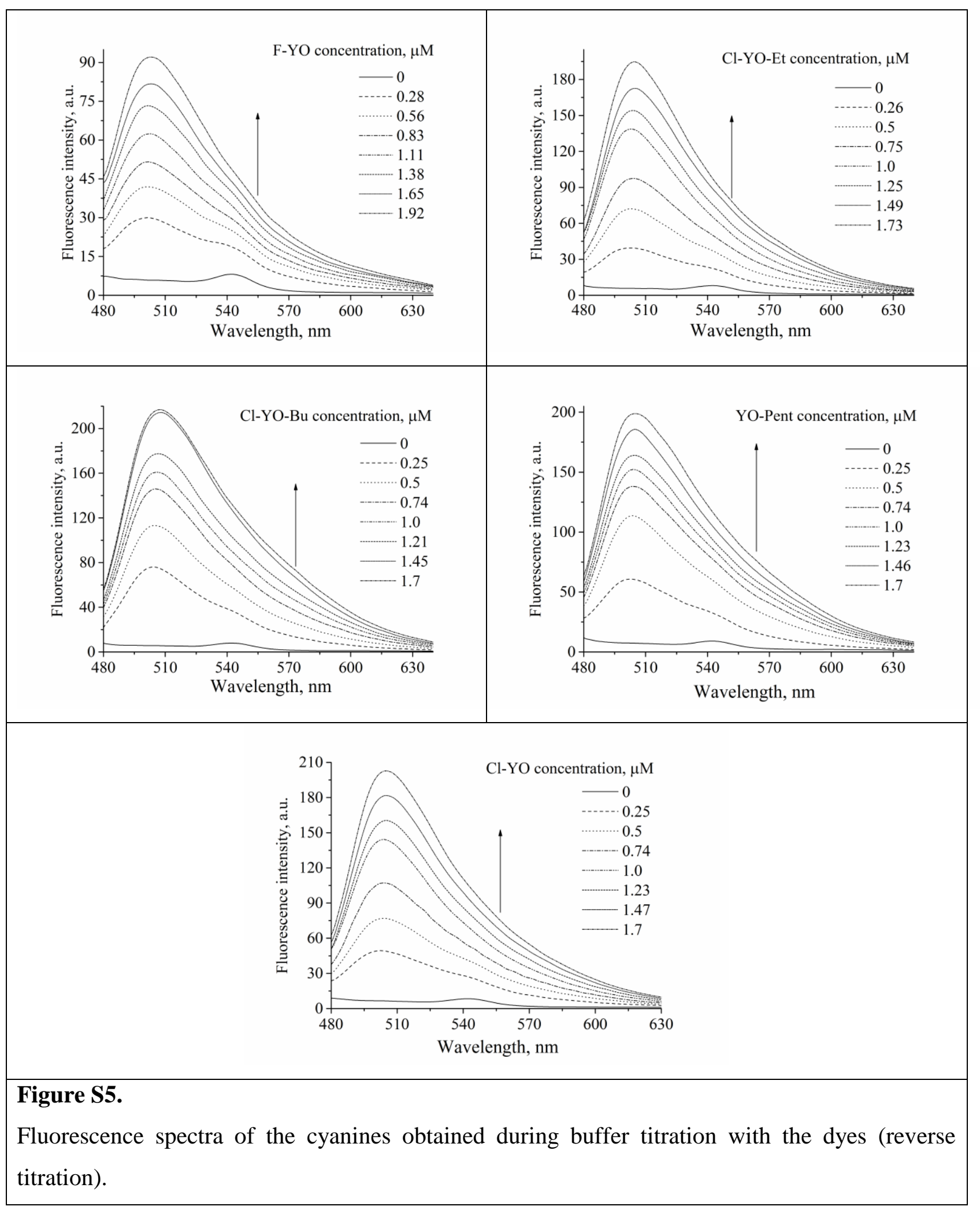




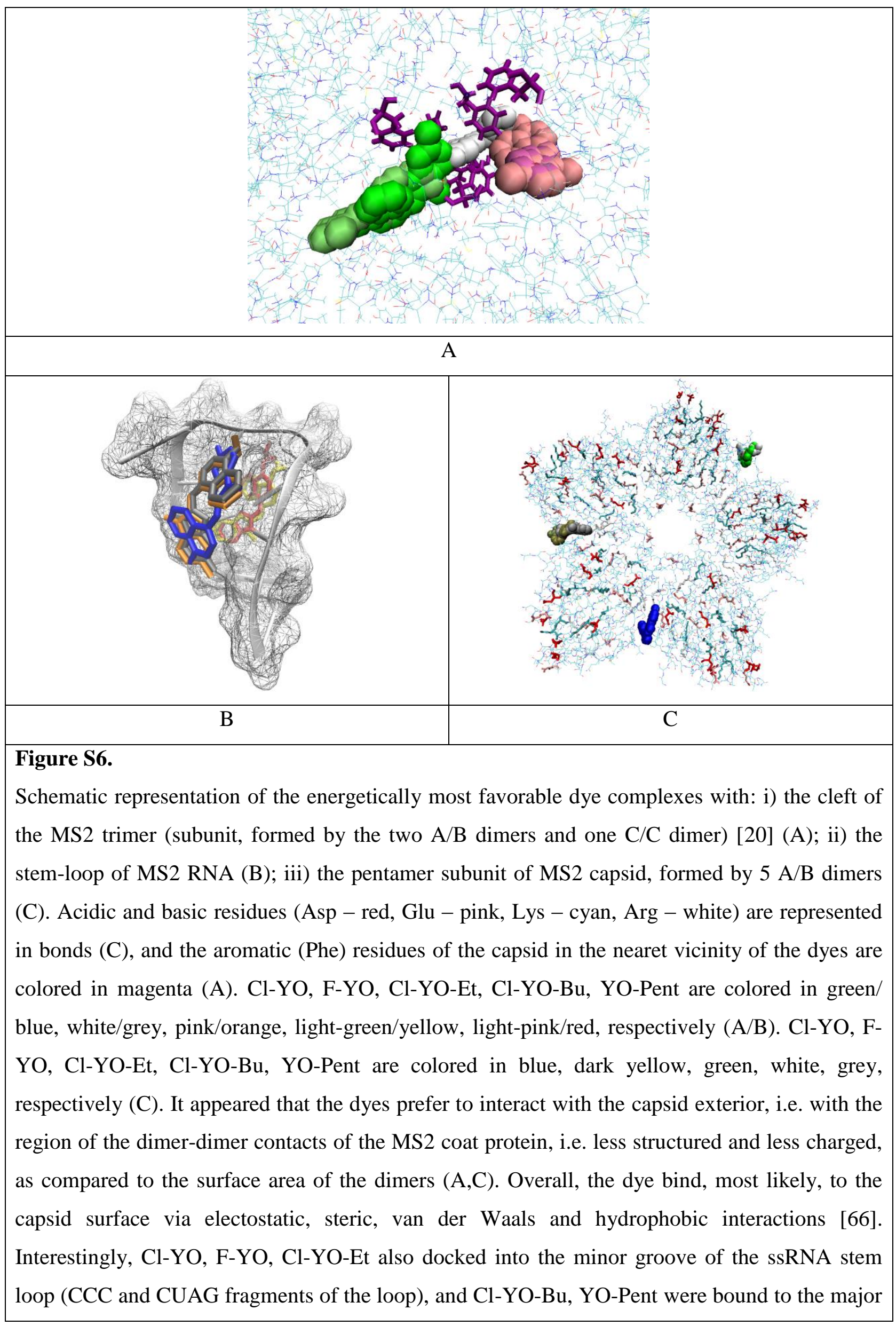


groove (CUAGG fragment, except the $U$ nucleotide), most likely via electrostatic and hydrophobic interactions (C) [31]. 


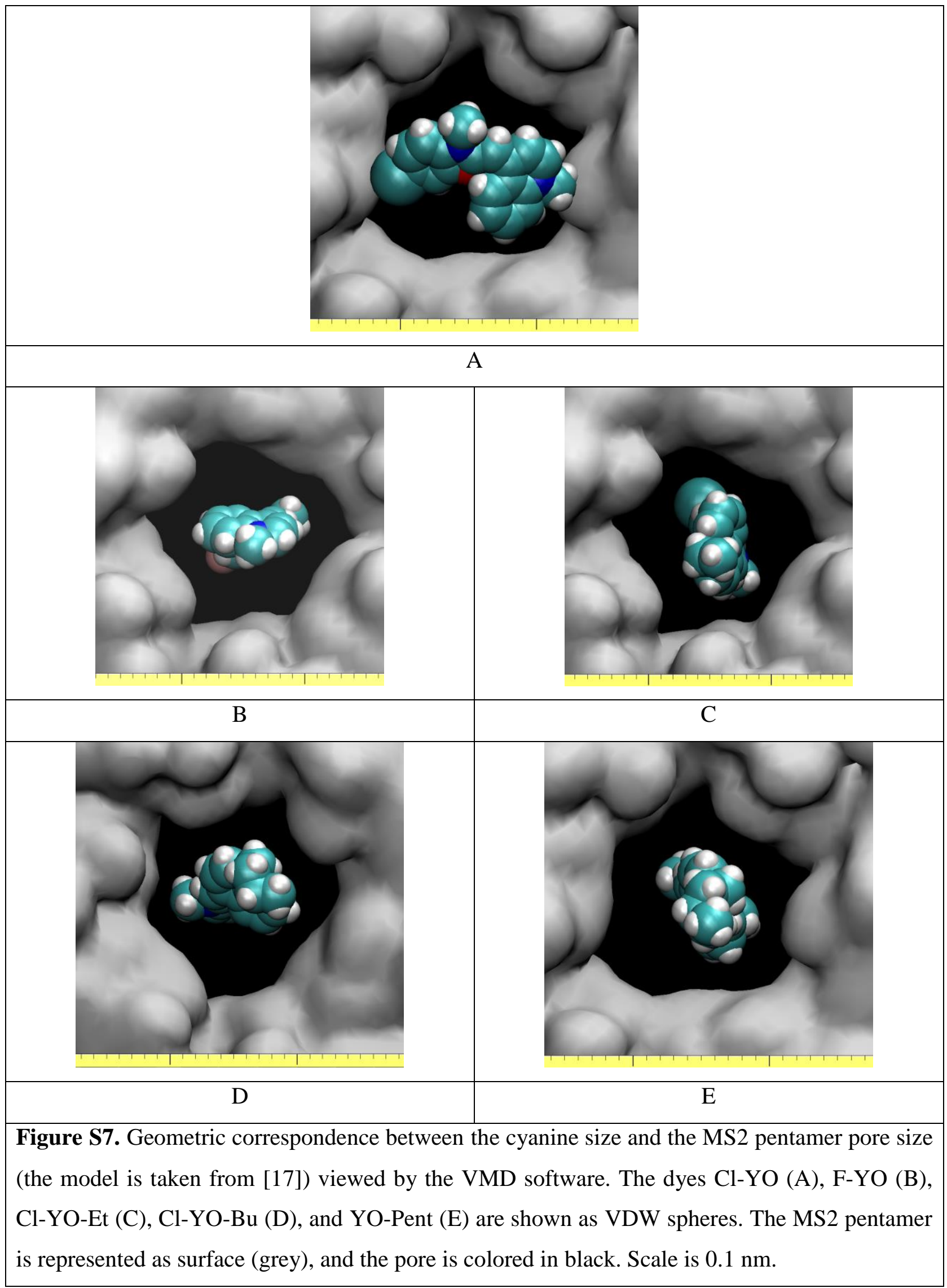




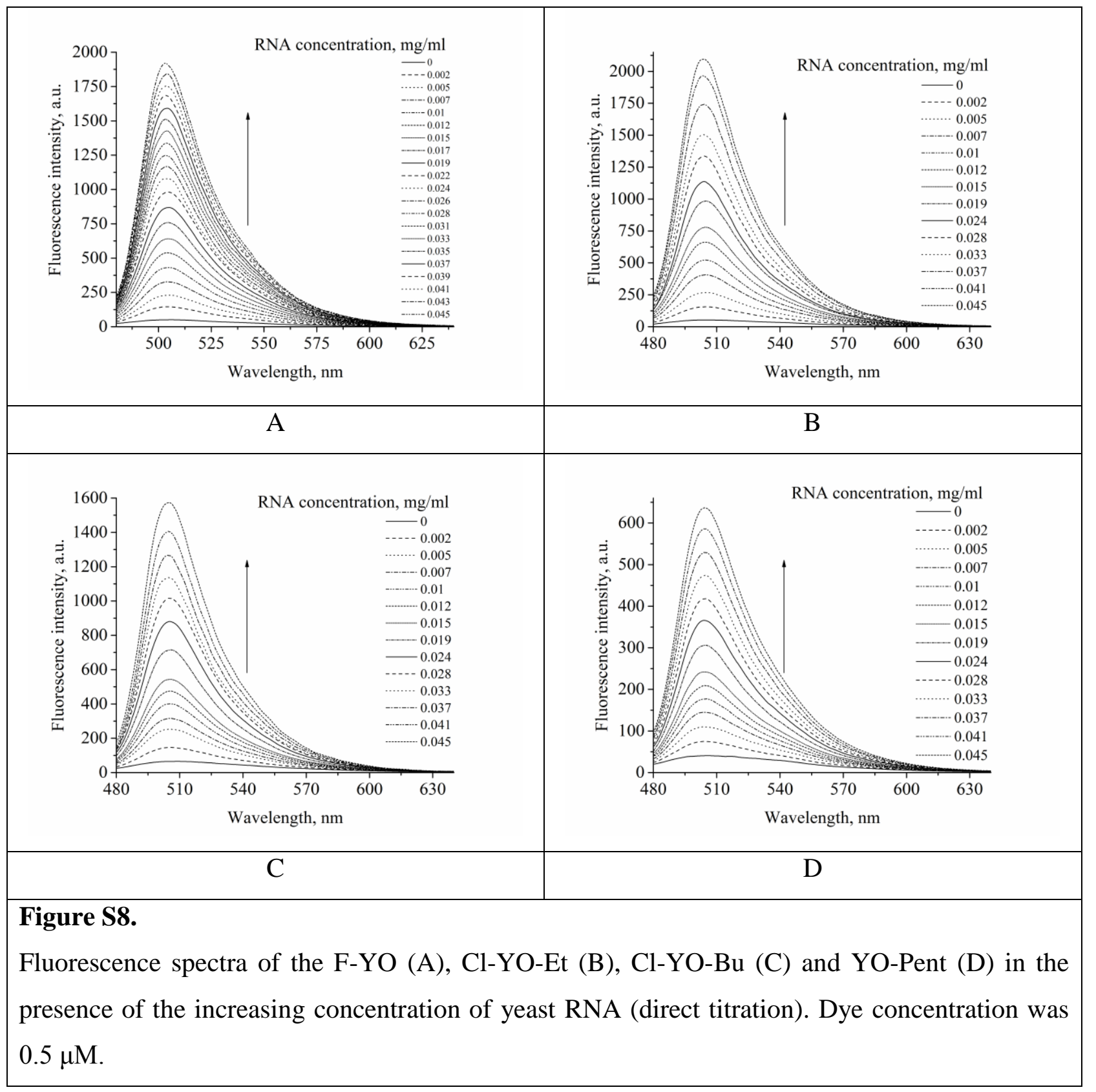




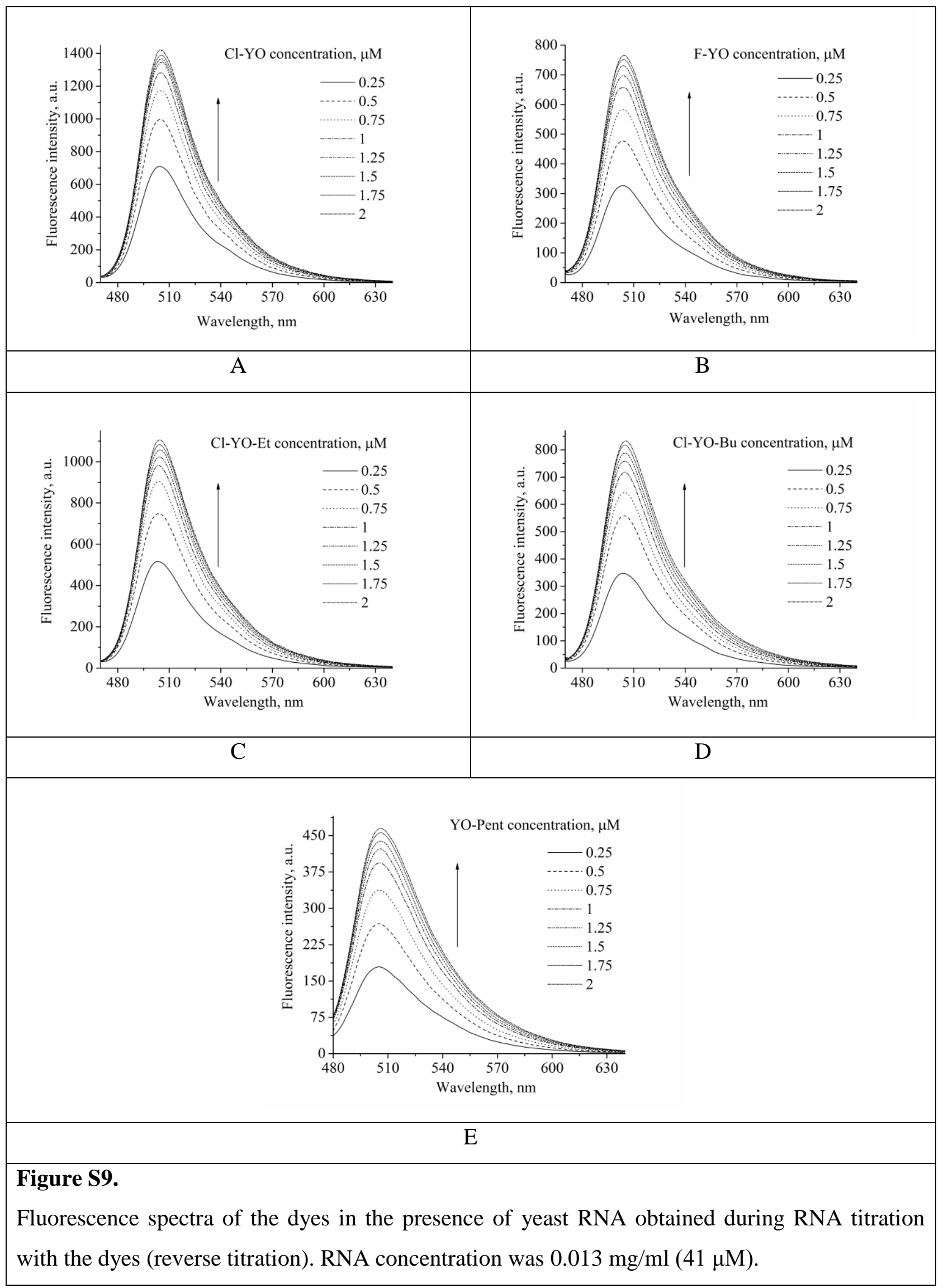




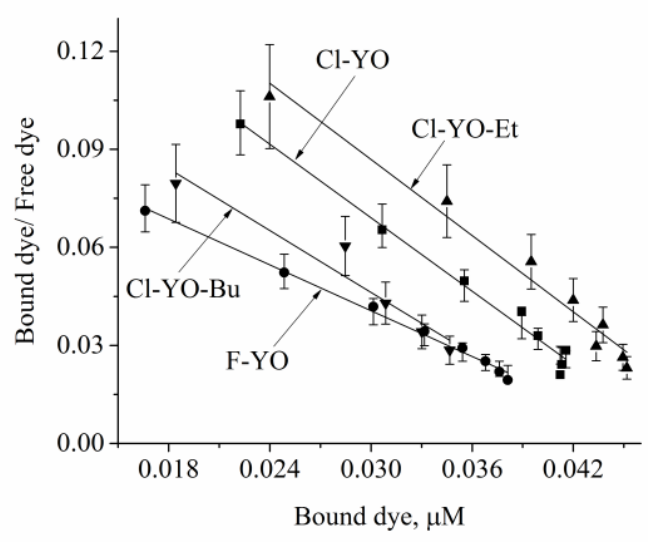

\section{Figure S10.}

Scatchard plots of the cyanine dyes in the presence of yeast RNA $(0.013 \mathrm{mg} / \mathrm{ml})$ at varying dye concentrations. Linear plots (except for YO-Pent, data not shown) reveal the one distinct binding mode of the probes to RNA.

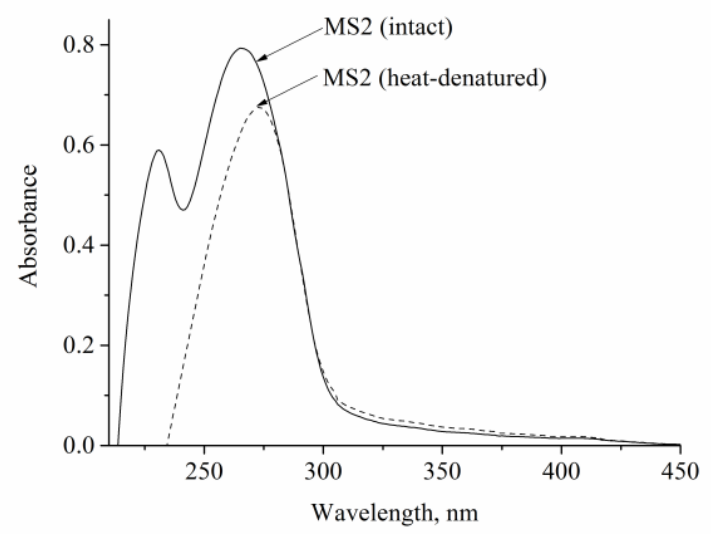

\section{Figure S11.}

Absorption spectra of the intact and heat-denatured ms2/s2. MS2 and RNase concentrations were $0.5 \mathrm{mg} / \mathrm{ml}$ and $0.93 \mathrm{mg} / \mathrm{ml}$, respectively. Spectra were corrected for turbidity as follows [87]: i) first, fitting of MS2 absorption spectra at $600-800 \mathrm{~nm}$ were performed using the equation $A_{\lambda}=P_{2} * \lambda^{-P_{1}}$ ( $A_{\lambda}$ is optical density at the wavelength $\lambda$ ), allowing the estimation of the parameters $P_{1}, P_{2}$, followed by calculation of the turbidity spectra $\left(A_{\lambda}\right)$ within the region 200 - $450 \mathrm{~nm}$; ii) next, turbidity curves were extracted from the measured data, and the resulting zspectra were plotted on the graph. 


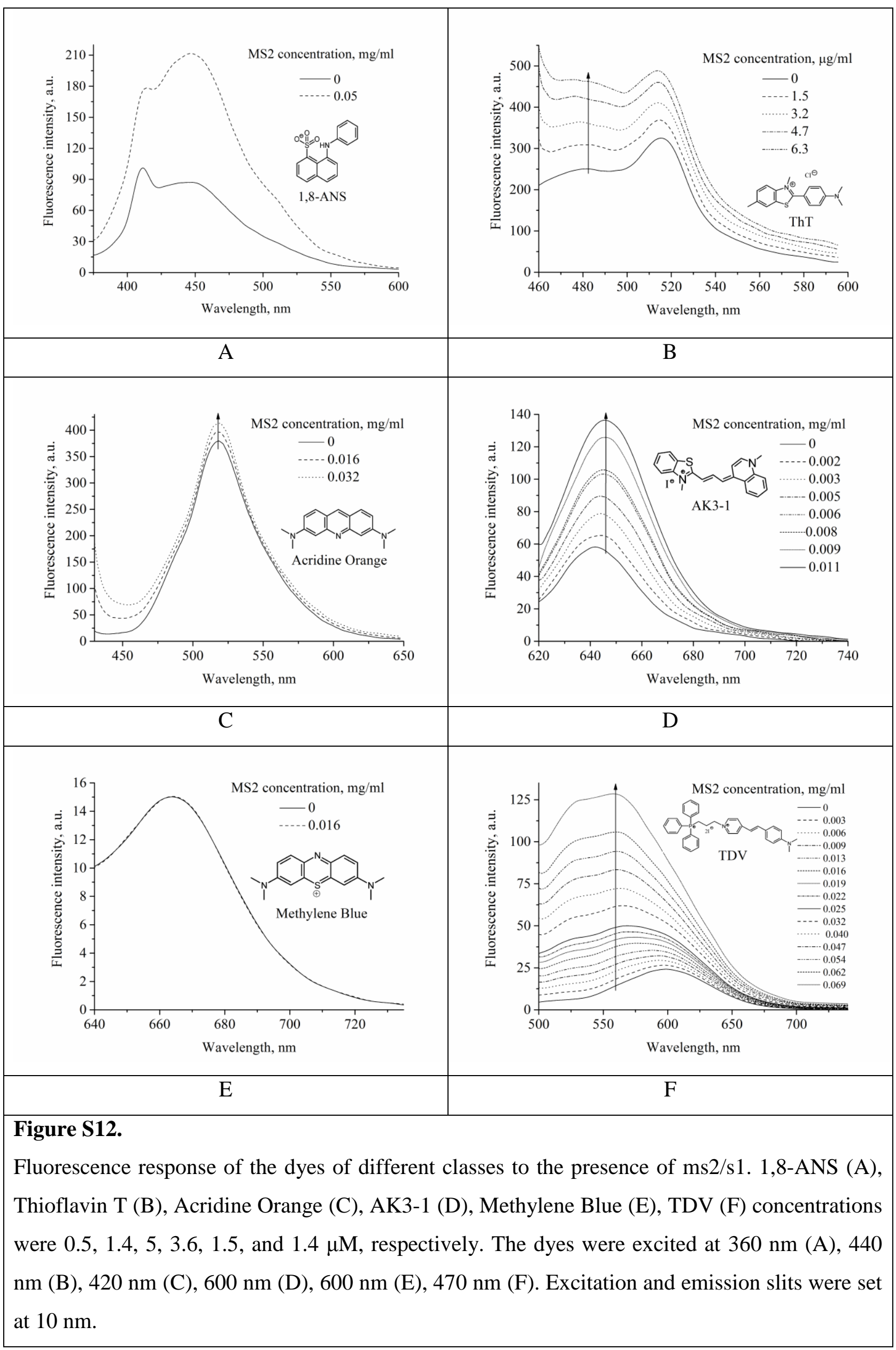


